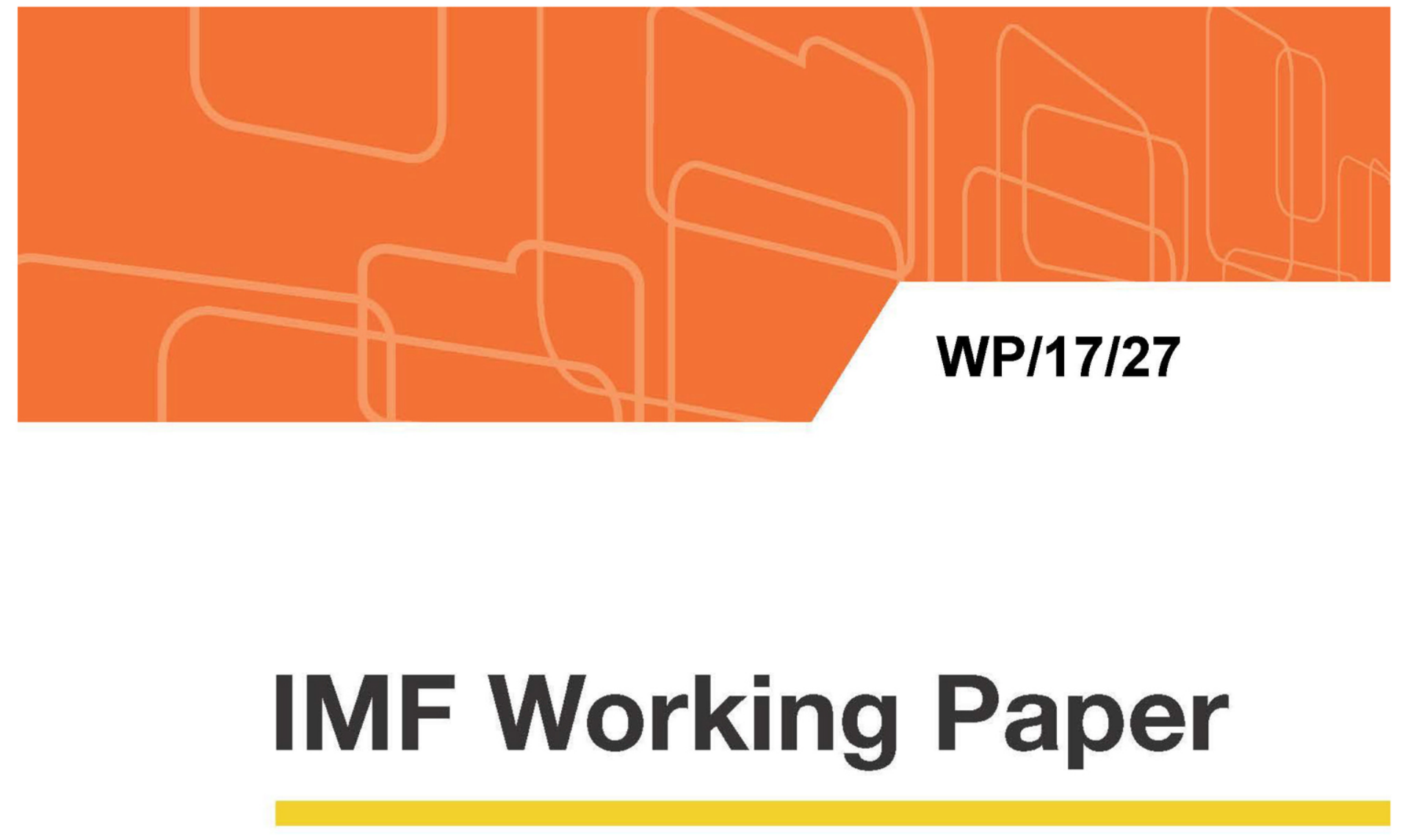

\title{
The Impact of Natural Resource Discoveries in Latin America and the Caribbean: A Closer Look at the Case of Bolivia
}

by Frederik Toscani

IMF Working Papers describe research in progress by the author(s) and are published to elicit comments and to encourage debate. The views expressed in IMF Working Papers are those of the author(s) and do not necessarily represent the views of the IMF, its Executive Board, or IMF management. 


\title{
WP/17/27
}

\section{IMF Working Paper}

\section{The Impact of Natural Resource Discoveries in Latin America and the Caribbean: A Closer Look at the Case of Bolivia}

\author{
by Frederik Toscani
}

IMF Working Papers describe research in progress by the author(s) and are published to elicit comments and to encourage debate. The views expressed in IMF Working Papers are those of the author(s) and do not necessarily represent the views of the IMF, its Executive Board, or IMF management. 


\title{
IMF Working Paper
}

Western Hemisphere Department

\section{The Impact of Natural Resource Discoveries in Latin America and the Caribbean: A Closer Look at the Case of Bolivia}

\author{
Prepared by Frederik Toscani ${ }^{1}$
}

Authorized for distribution by Krishna Srinivasan

February 2017

\section{IMF Working Papers describe research in progress by the author(s) and are published to elicit comments and to encourage debate. The views expressed in IMF Working Papers are those of the author(s) and do not necessarily represent the views of the IMF, its Executive Board, or IMF management.}

\begin{abstract}
This paper studies the impact of natural resource extraction in Latin America and the Caribbean (LAC) from a number of angles. First, we exploit a novel dataset on the universe of giant oil and gas discoveries in the region to trace out the cyclical response of macroeconomic variables to discoveries over the short- and medium-run. Second, we use non-stationary panel data techniques to look at the long-run (trend) relationship between GDP per capita and the value of oil and gas production-our results imply that the recent fall in prices could depress GDP per capita by several percentage points. Last, we use Bolivia, which discovered huge gas reserves in the late 1990s, as a case study to apply the crosscountry results and to study the impact of discoveries at the subnational level.
\end{abstract}

JEL Classification Numbers: O13, O40, O54

Keywords: Natural Resources, Discoveries, Economic Growth, Poverty

Author's E-Mail Address: ftoscani@imf.org

\footnotetext{
${ }^{1}$ I would like to thank participants at a seminar in La Paz organized by the Bolivian Ministry of Finance in October 2016 as well as Rabah Arezki, Manoj Atoli, Ravi Balakrishnan, Diego Cerdeiro, Kevin Dalrymple, Frederico Lima, and Kalin Tintchev for their helpful comments and suggestions.
} 


\section{Contents}

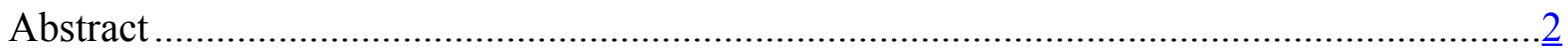

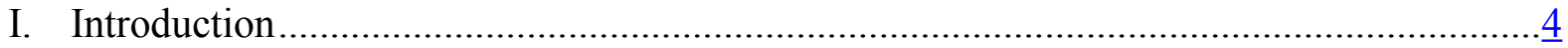

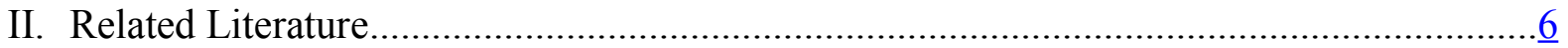

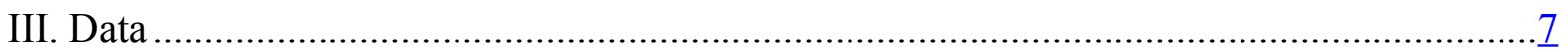

IV. The Impact of Oil and Gas Production on LAC Economies .......................................... $\underline{8}$

A. The Recent Resource Boom in Latin America and the Caribbean ...............................

B. The Short-Run Impact of Resource Discoveries: Evidence from Giant Oil and Gas

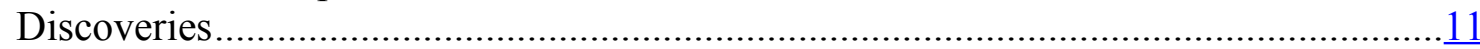

C. The Long-Run Impact of Resource Production on GDP: Evidence from Non-Stationary

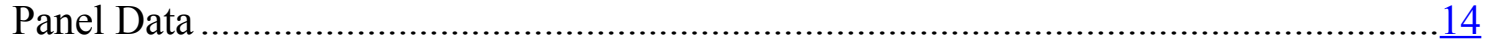

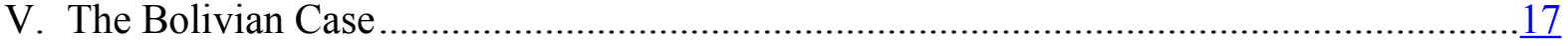

A. Overview and Macroeconomic Developments .......................................................17

B. The Impact of the Natural Resource Boom on Local Economic Development..............18

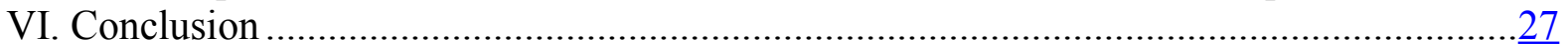

\section{Figures}

1. LAC's Share of Worldwide Giant Oil and Gas Discoveries by Decade ........................... $\underline{8}$

2. Oil and Natural Gas Production in LAC by Year and Country ....................................... $\underline{9}$

3. Real Value of Oil \& Natural Gas Production Per Capita in Selected LAC Countries in

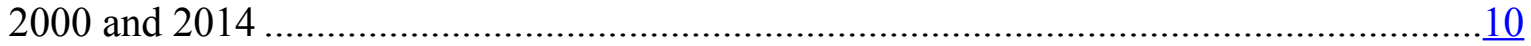

4. Impact of Giant Oil and Gas Discoveries on LAC Economies .....................................13

5. Long-Run Impact of Value of Oil and Gas Production on GDP Per Capita .....................17

6. GDP Per Capita and Value of Oil and Gas Production in Bolivia.................................... 18

7. Poverty Reduction and Change in Employment Composition in Bolivia ...........................20

8. Illustration of Difference in Difference Approach.......................................................

9. Impact of Natural Resource Boom on Extractive Sector Municipalities ..........................24

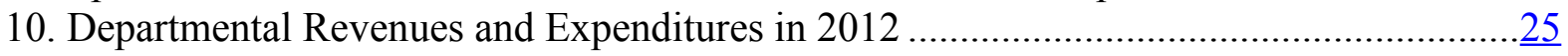

11. Real Sectoral GDP Growth Tarija vs the Rest of Bolivia...........................................26

\section{Tables}

1. Impact of Giant Oil and Gas Discoveries on LAC Economies ........................................14

2. Cross-Sectional Dependence, Unit Root and Co-Integration Tests.................................15

3. GDP Per Capita and Value of Oil and Gas Production Per Capita in the Long-Run ...........16

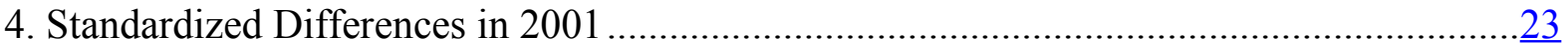

5. Impact of Natural Resource Boom on Extractive Sector Municipalities...........................23

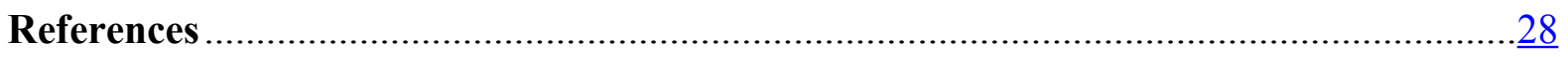

\section{Appendices}

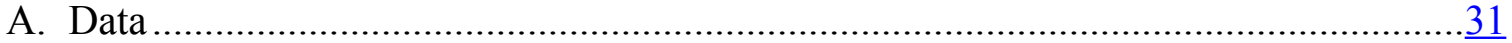

B. Brief Description of Extractive Sector Taxation in Bolivia.................................... 33

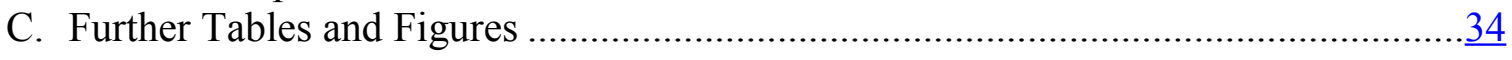




\section{INTRODUCTION}

At least since colonial times, natural resource extraction has been at the heart of many economies in Latin America and the Caribbean (LAC). During the colonial period, production of gold and silver took precedence but today LAC is an important producer of a diverse set of extractive resources, from copper and iron ore to crude oil and natural gas. According to a number of metrics of export concentration, South America (but not Central America) is one of the most commodity-dependent regions in the world (Adler and Sosa, 2011). Competing evidence discusses whether natural resource wealth throughout the years has been a blessing or a curse for LAC, with conflicting results pointing to Dutch disease type problems as well as weak institutions fueled by natural resource rents on the one hand, and the benefits of receiving a wealth windfall combined with positive real sector spillovers from resource extraction on the other hand (see, for example, World Bank, 2010).

This paper contributes to the debate by studying the following three questions: What is the impact of natural resource discoveries in the short- and medium-run? What is the long-term relationship between the value of natural resource production and GDP per capita? And lastly, what is the impact of natural resource production at the local (subnational) level? The (tentative) answers provided here aim to help our understanding of how natural resources impact national and sub-national economies in LAC over different time horizons.

To tackle the first question, we exploit a novel dataset on the universe of giant hydrocarbon discoveries to trace out the impact of discoveries on macroeconomic variables over a 10 -year period. In contrast to most previous work, we are thus able to comment on the impact of (plausibly exogenous) variation in volumes, rather than prices, on the economy. We show that the current account worsens immediately after a discovery as investment increases to develop the new field. The current account then very significantly improves once production starts. GDP growth is estimated to pick up immediately after the discovery but the impact dies down after a few years. The fiscal balance is unaffected at first but improves after production starts. On aggregate, our results indicate that in the short-run the discovery of natural resources (an asset) has the beneficial cyclical impact one would expect.

To shed light on the second question, which focuses on the long-run, we exploit the cointegrating relationship between GDP per capita and the value of oil and gas production in producer countries. ${ }^{1}$ We estimate that doubling the value of oil and gas production leads to an increase in GDP per capita of about $12-15$ percent on average. Heterogeneity across countries is

\footnotetext{
${ }^{1}$ The analysis here could also be interpreted as the long-run impact of discoveries. Discoveries increase the volume, and thus the value, of oil and gas production per capita for many years - in the most extreme cases, a large discovery makes a certain country an oil or gas producer for the first time.
} 
large, with the link particularly pronounced in the biggest per capita producers Trinidad and Tobago and Venezuela.

There are several ways to interpret this result - one is to say that in fact natural resource production is beneficial and that also over the long-run discoveries are thus a blessing rather than a curse. ${ }^{2}$ On the other hand, the result also points towards higher volatility of GDP. For a given level of production, the value of production fluctuates only with international prices. Given that prices of natural resources are much more volatile than those of manufacturing, a high sensitivity to resource prices can lead to well documented boom and bust cycles (World Bank, 2010). Taking our estimate at face value, the recent reduction of around 50 percent in international crude prices between August 2014 and end-2016 will eventually depress the level of GDP per capita in oil and gas producing LAC countries by 5-6 percent on average.

The other word of caution with regard to our long-run result relates to the link between natural resource extraction and a country's national wealth. The extraction of a natural resource is essentially a sale of an asset (Traa and Carare, 2007). Depending on how the revenues are used, this can lead to no growth in a country's wealth despite an accompanying increase in GDP per capita. If the revenues are invested in exploration (and thus the discovery of new assets) or productive human and physical capital, growth can increase together with wealth, but if the revenues are spent on current expenditures this might not be the case.

In the final part of the paper, we use Bolivia - which discovered huge natural gas fields in the late $1990 \mathrm{~s}$ - as a case study to shed additional light on the cross-country results and to study the local impact of natural resource extraction. In particular, we exploit municipal data from the 2001 and 2012 population census and estimate a simple difference-in-difference model to show that natural resource abundance has tended to be beneficial for local economic development. Poverty in natural resource rich municipalities (in particular, the ones with the gas megacampos) fell over and above the reduction in poverty for the country as a whole. Extractive sector municipalities also experienced a shift in employment away from (subsistence) agriculture and towards construction and manufacturing.

We find an interesting difference between the impact of hydrocarbon and metal extraction. Municipalities where the large gas fields are located received a much larger fiscal windfall than mining municipalities and as a consequence reduced poverty by more. However, likely due to the much lower labor intensity of gas production, they did not experience as many positive spillovers (measured by employment and net migration) to other sectors of the local economy as mining municipalities did. ${ }^{3}$

\footnotetext{
${ }^{2}$ The World Bank (2010) concludes that "the weight of the evidence seems to indicate that, on balance, there is no curse..." (p.13).

${ }^{3}$ Strictly speaking, most mining municipalities did not experience a discovery during the period of analysis so that the natural experiment is less clean. De facto, we are studying the impact of a price shock here.
} 
The remainder of the paper proceeds as follows. Section II briefly discusses the related literature while section III introduces the main datasets employed in this paper. Section IV presents the cross-country analysis while section V discusses the Bolivia specific analysis. Section VI concludes. Additional tables and figures not presented in the main text and supplementary discussion of data sources can be found in the appendix.

\section{RELATED LITERATURE}

This paper is related to a vast literature on the impact of natural resource wealth. Comprehensive reviews of the empirical cross-country literature as well as the theoretical models underpinning it are provided by van der Ploeg (2011), Ross (2012) and Venables (2016). For LAC, a thorough World Bank report (2010) collects available cross-country evidence as well as a large number of country-specific discussions. ${ }^{4}$ Many of those papers highlight the complex fiscal and political economy problems which countries need to solve in order to beneficially use natural resource wealth for development.

More specifically, the three parts of this paper each build on separate strands of the literature. The first section is directly related to a number of recent papers which exploit the variation generated by discoveries to assess the impact of natural resource abundance. Tsui (2011) studies the impact of crude oil discoveries on institutions and finds that they reduce democracy. Arezki et al. (2016a) are closest to the present study in terms of data and identification strategy but they focus on the impact of the news shock generated by discoveries prior to the start of production while we are interested in the overall short- and medium-run impact. Also, we focus specifically on LAC while their study covers a much larger set of countries.

Our work on the trend association between the value of production and income per capita is related to a large number of papers which study the relationship between resource abundance and economic outcomes in a cross-country setting. While most of those papers rely on standard panel data techniques (among many others, see the contributions by Sachs and Warner (1995), Gylfasson et al. (1999) and Alexeev and Conrad (2009) for contradictory results on the relationship between natural resource wealth and long-term GDP growth), our methodology closely follows Cavalcanti et al. (2014) who stress the importance of cross-sectional dependence and exploit the co-integrating relationship in the GDP and oil series.

Lastly, the local level analysis is related to a number of within country studies. Michaels (2011) as well as Alcott and Keniston show that in the U.S. (2014) oil production tends to lead to positive agglomeration effects, furthering local development. For developing countries, the evidence is more mixed, with a number of studies having focused on Brazil. Caselli and Michaels (2013) and Monteiro and Ferraz (2012) show that the fiscal windfall from oil tends to

\footnotetext{
${ }^{4}$ Also see Medina (2016) on the impact of commodity price shocks on fiscal aggregates in Latin America, and Gruss (2014) on likely lower growth in Latin America following lower international commodity prices.
} 
inefficiently spent. On the other hand, Cavalcanti et al. (2016) show that the pure market effect (abstracting from the fiscal channel) of having an oil sector is beneficial for Brazilian municipalities and leads to structural transformation over the long-run due to the positive demand and investment associated with it. Aragon and Rud (2013) show that a large gold mine in Peru lead to positive spillovers to the local economy, while Loayaza and Rigolini (2015) find that gold mines in Peru reduce local poverty. ${ }^{5}$ Our results on the differential impact of metal mining and natural gas production fit well with the above results for Brazil and Peru.

\section{DATA}

This paper combines data from a number of sources. In this section, we briefly discuss the key sources and data construction.

\section{Discovery Data}

Data on oil and gas discoveries is from Horn (2014). A giant discovery is defined as a discovery of an oil and/or gas field that contains at least a total of 500 million barrels of ultimately recoverable oil equivalent. The discovery data is available since the early $20^{\text {th }}$ century. The largest discoveries in Latin America over the past decades were in Mexico in 1977 and in Brazil in 2009 as well as discoveries in Venezuela. However, when we scale the discoveries by population, the ones in Bolivia in the late 1990s are among the very largest.

\section{Macroeconomic Variables}

Most macroeconomic variables are taken from the IMF WEO database. Real GDP in 2010 US\$ is taken from the ERS International Macroeconomic Database.

\section{Bolivia Specific Data}

Most data are taken from the national population censuses of 2001 and 2012 which are provided by the national statistics institute (INE). Departmental national accounts also come from INE, while departmental fiscal data comes from the Ministry of Finance.

Data on which municipalities produce oil, natural gas or metals was provided by Fundacion Jubileo (2016).

\footnotetext{
${ }^{5}$ Also see Fundacion Jubileo (2016) for a discussion of the local effect of natural resource extraction in Bolivia. In a study of convergence between Bolivian municipalities, Sillo and Gomez (2014) show that Bolivian municipalities have been converging at an accelerating pace since 2006, particularly for those municipalities which received higher revenues per capita, among which municipalities in the extractive sector departments of Tarija and Potosi are prominently represented.
} 
The following section establishes a few stylized facts about natural resource discoveries and production in LAC using the above discovery data before proceeding to the formal analysis.

\section{The Impact of OIL ANd Gas Production on LAC Economies}

\section{A. The Recent Resource Boom in Latin America and the Caribbean}

Even though LAC has always been an important natural resource producer, known reserves are relatively low compared to advanced countries (World Bank, 2010) indicating the potential for large additional discoveries. Indeed, LAC's share of worldwide discoveries has continuously increased over the past decades, quadrupling between the 1960s and the 2000s (Figure 1). ${ }^{6}$ Both the number of discoveries, as well as the number of very large discoveries increased, so that between 2000-09, LAC accounted for over 20 percent of the worldwide volume of oil and gas discoveries.

\section{Figure 1. LAC's Share of Worldwide Giant Oil and Gas Discoveries by Decade}

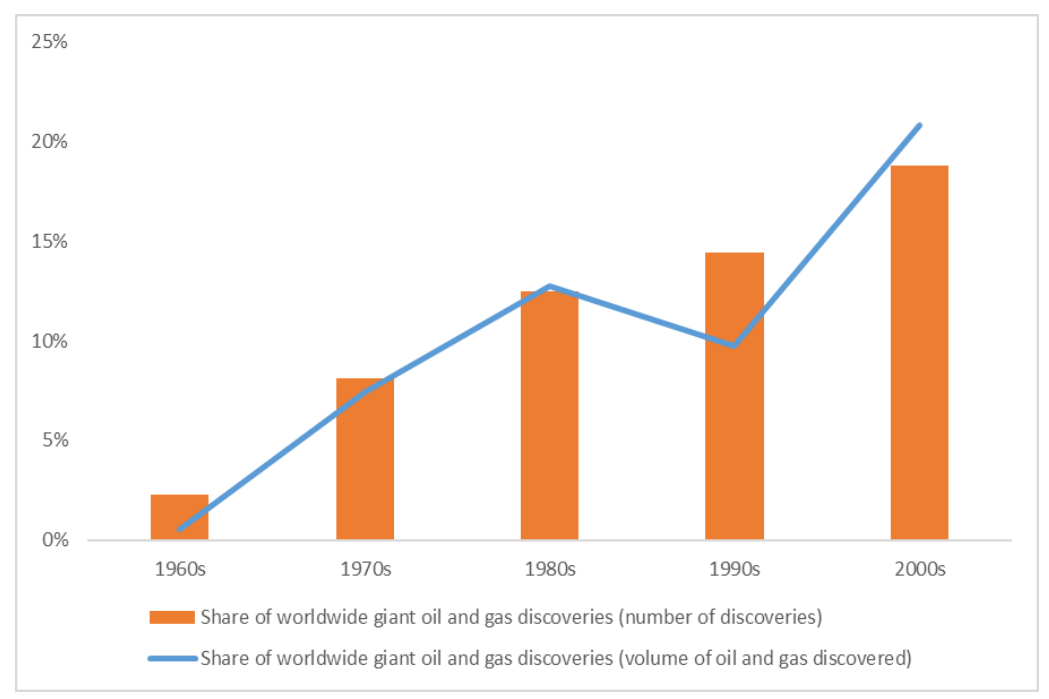

Source: Author's calculations based on data by Mike Horn.

As a consequence of these large and increasing discoveries, LAC was ideally placed to take advantage of the rising prices associated with the commodity boom. Indeed, figure 2 and 3 , respectively, show how the volume of oil and gas production steadily increased in LAC, and as a consequence of both the volume and prices increases, the value of hydrocarbon production per capita increased. While Trinidad and Tobago and Venezuela stand out as the largest producers in per capita terms (with a real value of production close to US $\$ 10,000$ per year in the case of Trinidad and Tobago) a number of other countries are also large per capita producers. For countries such as Bolivia, Colombia and Ecuador the real value per capita is estimated at between US\$600 and 1,400 - significant sums relative to their GDP per capita.

\footnotetext{
${ }^{6}$ Likely as a consequence of improved policies and institutions (see Arezki et al. (2016b)).
} 
Figure 2. Oil and Natural Gas Production in LAC by Year and Country

(a) Crude Oil

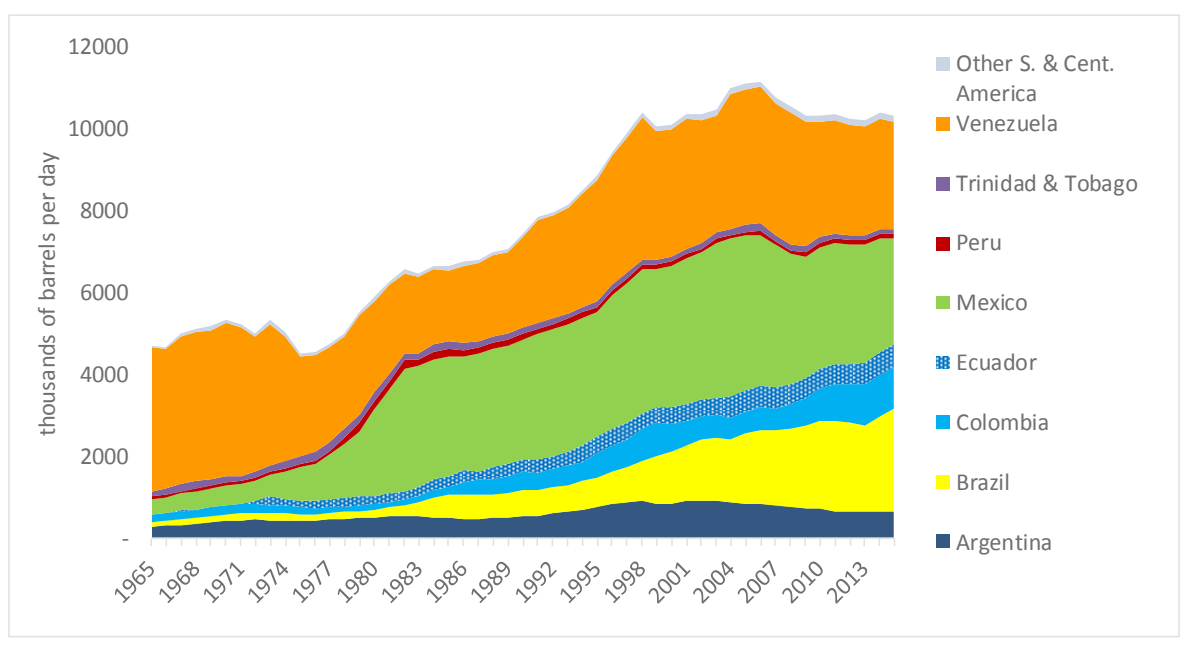

(b) Natural Gas

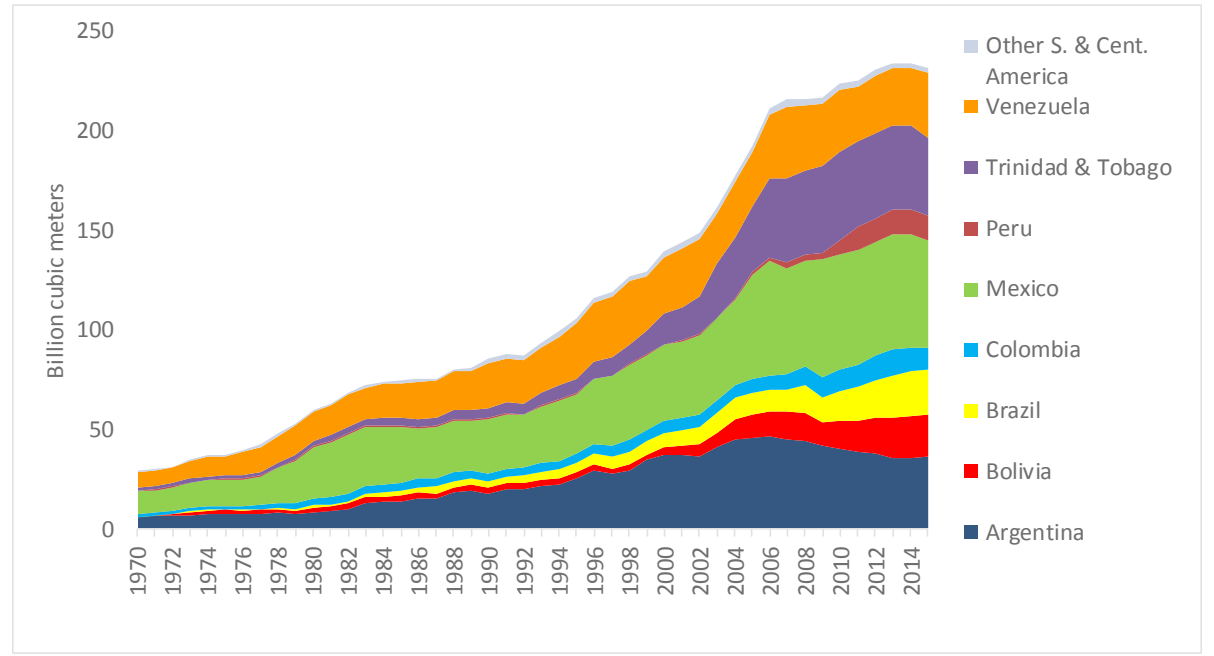

Source: Author's calculations based on data by BP (2015).

CInternational Monetary Fund. Not for Redistribution 
Figure 3. Real Value of Oil and Natural Gas Production Per Capita in Selected LAC Countries in 2000 and 2014

(a) the Producer Countries

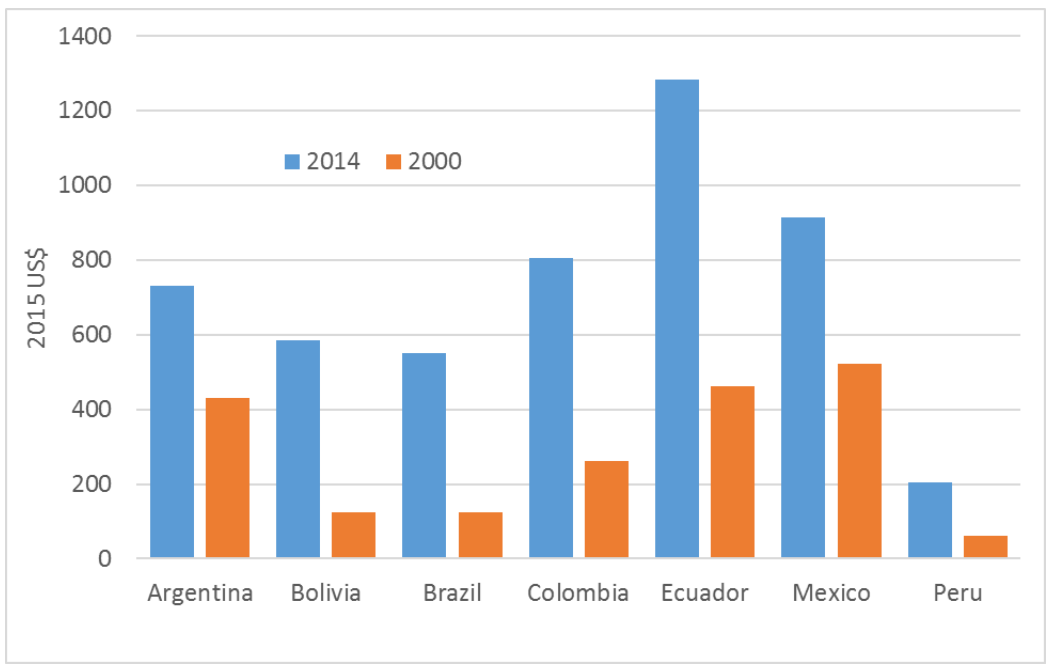

(b) the Very Large Producers

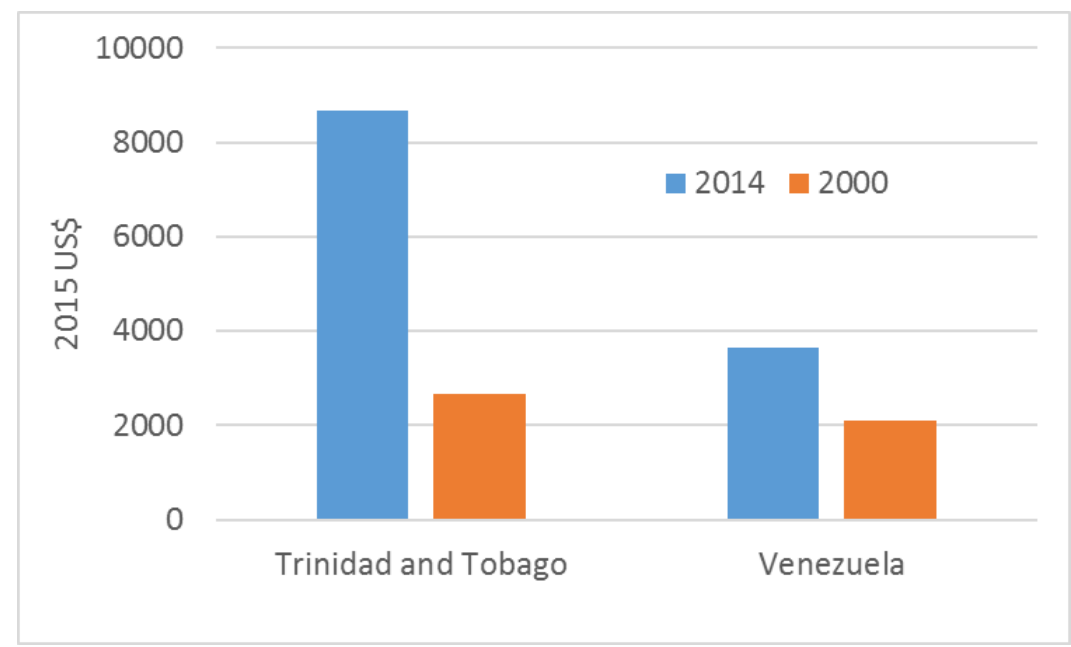

Source: Author's calculations based on data by the OECD and IMF WEO. 


\section{B. The Short-Run Impact of Resource Discoveries: Evidence from Giant Oil and Gas Discoveries}

Giant discoveries allow us to identify plausibly exogenous and economically significant variation in oil and gas production. To test for the impact of discoveries on the macro-economy over the short- and medium-run we estimate the following regression model. ${ }^{7}$

$$
y_{i t}=\alpha+B(Q) D_{i t}+\gamma_{i}+\rho_{t}+\varepsilon_{i t}
$$

where $y_{i t}$ is the dependent variable for country $i$ at time $t, B(Q)$ is a qth order lag operator, $D_{i t}$ is the per capita volume of oil and gas discoveries in country $i$ at time $t$ and $\gamma_{i}$ and $\rho_{t}$ are country and time fixed effects, respectively.

This simple specification aims to trace out the impact of a discovery over a number of years by including a large number of lags. Additionally, it controls for country and year fixed effects, implying the usual advantage of controlling for time invariant country characteristics (such as geology and geography) and common shocks (such as movements in oil prices). We scale discoveries by population to avoid that a few large discoveries in large countries drive all the variation.

Our period of analysis is 1980-2014. In our baseline regressions we choose a lag length of 10 but results are robust to alternative lag lengths. Standard errors are clustered at the country level in all specifications. We work with five dependent variables: growth of oil and gas production, growth of GDP per capita, growth of gross fixed capital formation (GFCF), the current account balance, and the primary fiscal balance. We use the growth rates rather than the level of GDP and GFCF since we find those series to be non-stationary. On the other hand, the current account balance and the fiscal balance do not have a unit root so we use the level of the series. Lastly, in our baseline regression as specified in equation (I) we do not include a lagged dependent variable to have the most tractable and transparent results possible, but in robustness exercises we do include it to be able to capture richer dynamics. ${ }^{8}$

Figure 4 and Table 1 summarize the main results of the exercise. In particular, the panels show the point estimates and 90 percent confidence interval of the estimated $B(Q)$ coefficients. The first panel on top shows results for the growth in the value and oil and gas production as the dependent variable, while the following four panels show results for the key macroeconomic variables of interest. The graphs are scaled to represent the impact of an average discoverycorresponding to roughly 40 barrels of oil and gas equivalent per capita.

\footnotetext{
${ }^{7}$ See Arezki et al. (2016a) for a very similar set-up.

${ }^{8}$ The drawback to including the lagged dependent variable is the well-known Nickell bias (1981). Since the bias is of order (1/T) and we have a relatively long panel of over 30 years this appears manageable, however.
} 
The following picture emerges. Hydrocarbon production picks ups after roughly 3-5 years with the point estimate of the growth impact converging to 0 after another few years. Gross fixed capital formation growth picks up immediately as the new discovery is being developed which leads to an immediate worsening in the current account. This worsening is reversed as hydrocarbon production starts with the positive effect peaking at about 2 percent of GDP after 8 years. GDP growth increases in the first four years, so mainly during the development phase of the project, and point estimates of the growth impact settle at 0 thereafter. The fiscal balance does not react for a number of years but markedly improves towards the end of the estimation period. ${ }^{9,10}$

Overall, this is roughly the impact to a discovery which one would expect based on standard macroeconomic theory. ${ }^{11}$ Agents increase investment to take advantage of the news of higher production potential and once production starts, the current account improves. From a policy perspective, given the large fluctuations in the current account associated with giant discoveries, it is important for policy makers to be ready to react in an appropriate manner. ${ }^{12}$

In terms of GDP growth, the results indicate an immediate bounce which flattens off after 5 years but is not reversed (and hence tentatively indicates a permanent increase in the level of GDP). One important way in which discoveries impact GDP is by changing the production side of the economy - giant discoveries have the potential to significantly alter the output and export composition of (especially less sophisticated) economies. In the next section we explicitly study the long-term relationship between natural resource production and GDP per capita.

\footnotetext{
${ }^{9}$ It is worth pointing out that only a number of the point estimates are significant at standard confidence levels, in particular when the dependent variable is specified as a growth rate. This is for two reasons-first, there is some heterogeneity in the exact timing of the reaction to the discovery and second, a number of small increases in growth rates can individually not be significant but still significantly raise the level. Having said that, for all variables at least two lags are statistically significant, indicating a significant increase in the level of the dependent variable.

${ }^{10}$ Using the real effective exchange rate (which might be expected to appreciate) as the dependent variable does not give any statistically significant results.

${ }^{11}$ Arezki et al. (2016a) develop a dynamic two-sector economy and show that the 'news shock' about increased future production associated with a discovery should lead agents to increase investment immediately and thus worsen the current account immediately. This effect is reversed once production actually starts.

12 In robustness exercises we include a number of control variables in the regressions such as trade openness. Results are available on request.
} 
Figure 4. Impact of Giant Oil and Gas Discoveries on LAC Economies
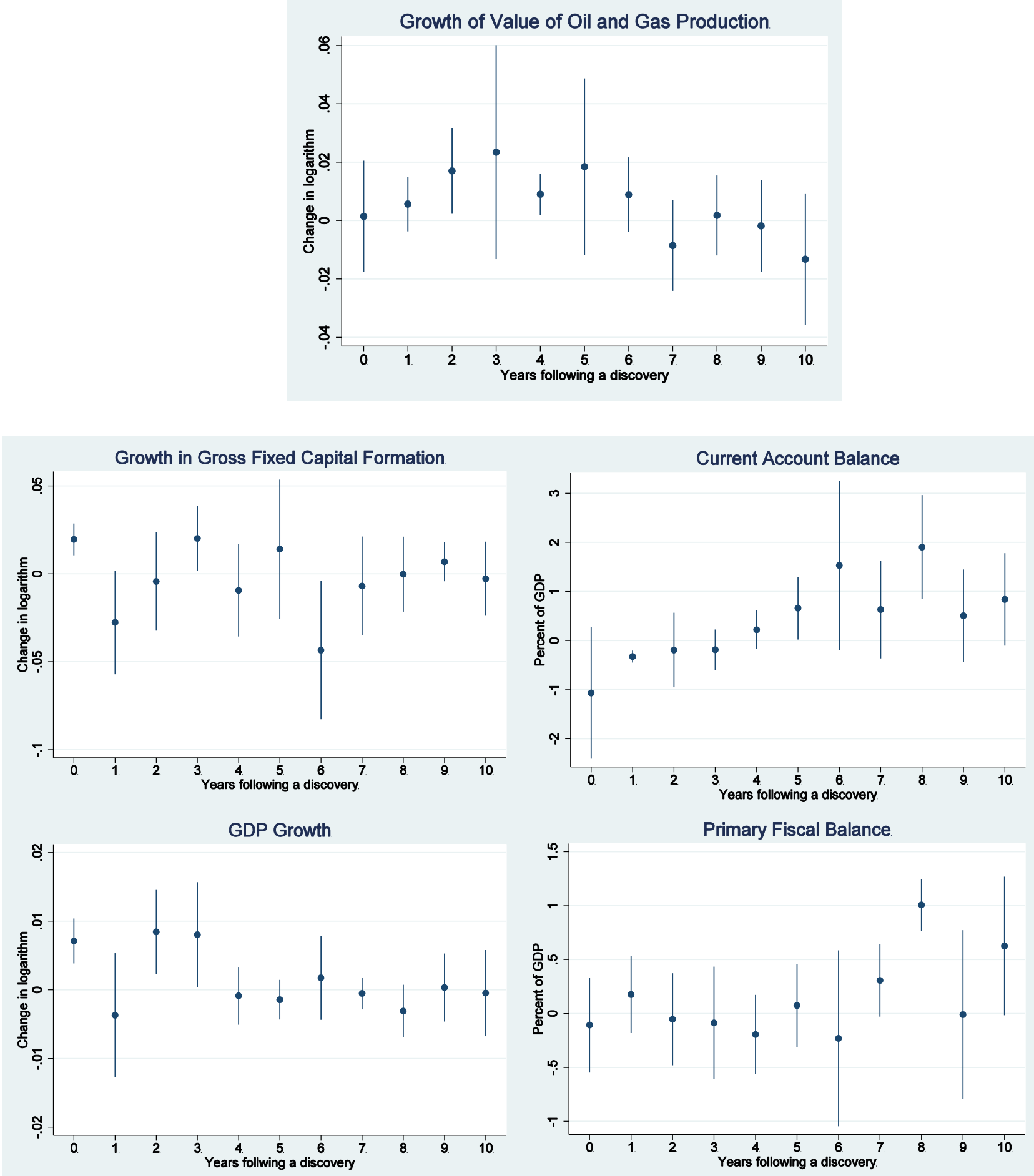

Source: Author's calculations.

Notes: The results show the impact on macroeconomic variables of the mean giant oil and gas discovery in Latin America and the Caribbean (roughly 40 barrels of oil equivalent per capita- a windfall of roughly US\$2,000 per capita, depending on the international price of oil, cost of extraction, etc.). 
Table 1. Impact of Giant Oil and Gas Discoveries on LAC Economies

\begin{tabular}{|c|c|c|c|c|c|}
\hline VARIABLES & $\begin{array}{l}\text { (1) } \\
\text { Growth in Value of Oil and Gas Production per Capita }\end{array}$ & $\begin{array}{c}\text { (2) } \\
\text { Growth in Gross Fixed Capital Formation }\end{array}$ & $\begin{array}{c}\text { (3) } \\
\text { Current Account as \% of GDP }\end{array}$ & $\begin{array}{c}\text { (4) } \\
\text { Growth in Real GDP per Capita }\end{array}$ & $\begin{array}{c}(5) \\
\text { Primary balance in \% of GDP }\end{array}$ \\
\hline \multirow{2}{*}{ Volume of discoveries per capita } & $3.57 \mathrm{e}-05$ & $0.000489^{* * *}$ & -0.0267 & $0.000178^{* * *}$ & -0.00266 \\
\hline & $(0.000265)$ & $(0.000131)$ & $(0.0193)$ & $(4.73 \mathrm{e}-05)$ & $(0.00637)$ \\
\hline \multirow{2}{*}{ Volume of discoveries per capita, lagged } & 0.000141 & -0.000691 & $-0.00816 * * *$ & $-9.25 \mathrm{e}-05$ & 0.00440 \\
\hline & $(0.000130)$ & $(0.000425)$ & $(0.00178)$ & $(0.000131)$ & $(0.00516)$ \\
\hline \multirow[t]{2}{*}{ Volume of discoveries per capita, 12} & $0.000426^{*}$ & -0.000108 & -0.00481 & $0.000211^{* *}$ & -0.00133 \\
\hline & $(0.000205)$ & $(0.000403)$ & $(0.0110)$ & $(8.84 \mathrm{e}-05)$ & $(0.00617)$ \\
\hline \multirow[t]{2}{*}{ Volume of discoveries per capita, 13} & 0.000586 & $0.000504^{*}$ & -0.00467 & $0.000201^{*}$ & -0.00218 \\
\hline & $(0.000510)$ & $(0.000265)$ & $(0.00598)$ & $(0.000111)$ & $(0.00754)$ \\
\hline \multirow[t]{2}{*}{ Volume of discoveries per capita, 14} & $0.000226 * *$ & -0.000235 & 0.00552 & $-2.17 \mathrm{e}-05$ & -0.00487 \\
\hline & $(9.84 \mathrm{e}-05)$ & $(0.000379)$ & $(0.00574)$ & $(6.08 \mathrm{e}-05)$ & $(0.00532)$ \\
\hline \multirow[t]{2}{*}{ Volume of discoveries per capita, 15} & 0.000462 & 0.000352 & $0.0165^{*}$ & $-3.60 \mathrm{e}-05$ & 0.00187 \\
\hline & $(0.000421)$ & $(0.000570)$ & $(0.00923)$ & $(4.17 \mathrm{e}-05)$ & $(0.00559)$ \\
\hline \multirow[t]{2}{*}{ Volume of discoveries per capita, 16} & 0.000222 & $-0.00109^{*}$ & 0.0383 & $4.37 \mathrm{e}-05$ & -0.00576 \\
\hline & $(0.000178)$ & $(0.000566)$ & $(0.0249)$ & $(8.84 \mathrm{e}-05)$ & $(0.0118)$ \\
\hline \multirow[t]{2}{*}{ Volume of discoveries per capita, 17} & -0.000214 & -0.000173 & 0.0158 & $-1.31 \mathrm{e}-05$ & 0.00767 \\
\hline & $(0.000216)$ & $(0.000405)$ & $(0.0144)$ & $(3.36 \mathrm{e}-05)$ & $(0.00485)$ \\
\hline \multirow[t]{2}{*}{ Volume of discoveries per capita, 18} & $4.44 \mathrm{e}-05$ & $-5.40 \mathrm{e}-06$ & $0.0476^{* * *}$ & $-7.74 \mathrm{e}-05$ & $0.0252^{* * *}$ \\
\hline & $(0.000191)$ & $(0.000307)$ & $(0.0153)$ & $(5.54 \mathrm{e}-05)$ & $(0.00349)$ \\
\hline \multirow{2}{*}{ Volume of discoveries per capita, 19} & $-4.58 \mathrm{e}-05$ & 0.000172 & 0.0126 & $8.36 \mathrm{e}-06$ & -0.000257 \\
\hline & $(0.000220)$ & $(0.000160)$ & $(0.0136)$ & $(7.16 \mathrm{e}-05)$ & $(0.0113)$ \\
\hline \multirow{2}{*}{ Volume of discoveries per capita, 110} & -0.000331 & $-6.93 \mathrm{e}-05$ & 0.0209 & $-1.21 \mathrm{e}-05$ & 0.0157 \\
\hline & $(0.000314)$ & $(0.000303)$ & $(0.0136)$ & $(9.06 \mathrm{e}-05)$ & $(0.00930)$ \\
\hline \multirow[t]{2}{*}{ Constant } & 0.193 & 0.0177 & $-4.820^{* * *}$ & 0.00351 & $-6.870^{* * *}$ \\
\hline & $(0.147)$ & $(0.0513)$ & $(1.310)$ & $(0.0140)$ & $(0.105)$ \\
\hline Observations & 366 & 551 & 616 & 616 & 413 \\
\hline Country FE & Yes & Yes & Yes & Yes & \\
\hline Year FE & Yes & Yes & Yes & Yes & \\
\hline R-squared & 0.757 & 0.314 & 0.235 & 0.332 & 0.314 \\
\hline Number of ifs_code & 12 & 19 & 20 & 20 & 20 \\
\hline
\end{tabular}

\section{The Long-Run Impact of Resource Production on GDP: Evidence from Non-Stationary Panel Data}

Here we are interested in studying the relationship between oil and gas production and gross domestic product. Our approach closely mirrors the one employed by Cavalcanti et al. (2014). In particular, we test for and acknowledge the unit root and the co-integrating relationship in the series. Additionally, we take account of cross-sectional dependence, another important feature of the data - shocks to oil prices or U.S. growth, for example, are likely to affect GDP in all hydrocarbon producing countries in LAC, but to different degrees. We explicitly test for crosssectional dependence in the data and then account for it by using Pesaran's Common Correlated Effects estimator (2006).

Table 2 shows the results of testing for cross-sectional dependence, unit roots and co-integration. The first columns show that we can reject the null hypothesis of no cross-sectional dependence at very high confidence levels. This feature of the data persists even if we were to work with first differences, particularly for the value of oil and gas production. Given that there is cross-sectional dependence, standard panel unit root tests can give misleading results, and we thus rely on the CIPS test which takes cross-sectional dependence into account (Pesaran, 2007). In most specifications, we conclude that the series contain a unit root. ${ }^{13}$ Lastly, we explicitly test for co-

\footnotetext{
${ }^{13}$ Results shown are for a model with trend. Without trend, the null hypothesis of the series being I(1) is never rejected for the levels and always rejected for the first differences. Similarly, results from standard panel unit root tests such as Maddala and Wu (1999) strongly suggest that the data are I(1).
} 
integration. There is no strong consensus in the literature on how to test for panel co-integration in the presence of cross-sectional dependence so we rely on the standard Pedroni mean group tests. All three tests strongly suggest that the value of oil and gas production per capita and GDP per capita are co-integrated. ${ }^{14}$

Table 2. Cross-Sectional Dependence, Unit Root and Co-Integration Tests

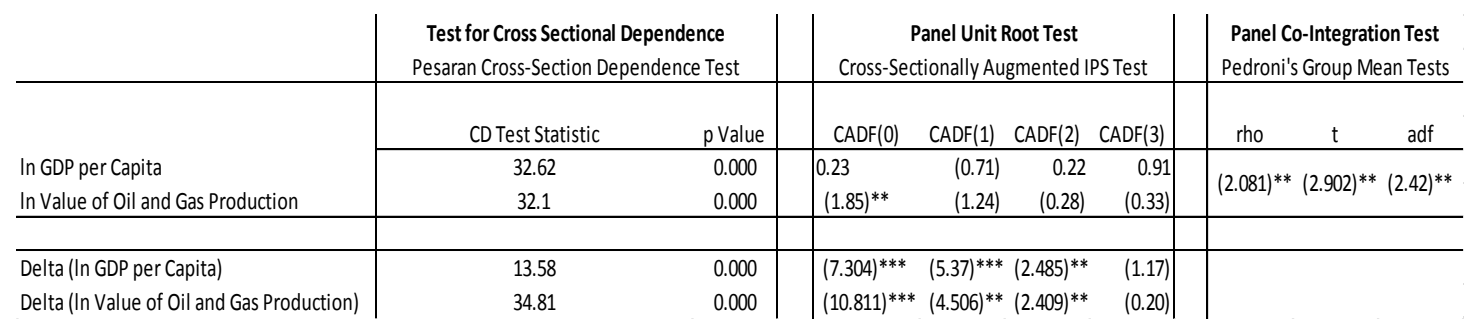

Source: Author's calculations.

Notes: The null hypothesis for the cross-sectional dependence test (CD) is no cross-sectional dependence. The null hypothesis for the panel unit root test (CIPS) is that the series is I(1). The null hypothesis for the panel co-integration test (PGM) is no co-integration. * indicates rejection at the 10 percent level, ** at the 5 percent level and *** at the 1 percent level, respectively.

Based on these results we estimate the following model

$$
\ln \left(g d p_{i t}\right)=\alpha_{i}+\beta_{i} \ln \left(o i l_{i t}\right)+\gamma_{i} t+\varepsilon_{i t}(\mathrm{II})
$$

where $g d p_{i t}$ is real GDP per capita in constant 2010 US\$ for country $i$ in year $t, o i l_{i t}$ is the real value of oil and gas production per capita in constant $2015 \mathrm{US} \$, \alpha_{i}$ is a country fixed effect, $\beta_{i}$ is a country-specific slope coefficient and $\gamma_{i} t$ are heterogeneous country-specific deterministic trends. The Common Correlated Effects estimator (CCE) augments the above OLS regression with cross-sectional averages of the dependent variable and of the regressors. The estimated coefficients on these averages are not easily interpreted but they remove cross-sectional dependence. Averaging across $\beta_{i}$ gives the average impact of oil production on GDP in LAC in the long-run - $\beta$.

The estimates in table 3 suggest that doubling the value of oil and gas production on average increases GDP per capita by 12-15 percent. Heterogeneity in the estimates is large, however. In the largest producer per capita, Trinidad and Tobago, the coefficient is estimated to be over 0.35. It is between 0.12 and 0.16 for Bolivia, Colombia and Ecuador (see figure 5). ${ }^{15}$

\footnotetext{
${ }^{14}$ If the series were I (1) but not co-integrated we would have to work with first differences but would face the standard endogeneity concerns.

${ }^{15}$ Chile, a small producer and net importer is excluded. Including it slightly reduces the estimated coefficients to $0.1-0.12$.
} 
The estimates suggest that large moves in the value of oil and gas production (as triggered by large discoveries or persistent changes in prices) have a sizeable impact on GDP on average. Taking the recent fall in oil prices of over 50 percent (which is expected to persist), could thus suggest a fall in GDP per capita of around 5-6 percent in hydrocarbon producing countries in LAC. ${ }^{16}$

It is important to stress that the present exercise is in some sense purely statistical - it does not tell us anything about economic mechanisms or channels, so the conclusions that can be drawn are limited. Nevertheless, the strong link between international oil prices and GDP still experienced by many hydrocarbon producers in LAC serves as a reminder of the imperative to diversify economies away from natural resources to reduce the volatility of output.

The following section uses Bolivia as a case study to apply and deepen the analysis.

\section{Table 3. GDP Per Capita and Value of Oil and Gas Production Per Capita in the Long-Run}

\begin{tabular}{lcc}
\hline \multirow{2}{*}{ VARIABLES } & $(1)$ & $(2)$ \\
& $\ln (\mathrm{gdp})$ & $\ln (\mathrm{gdp})$ \\
\hline In(oil) & $0.121^{* * *}$ & $0.148^{* * *}$ \\
& $(0.0159)$ & $(0.0269)$ \\
Constant & 0.133 & 0.120 \\
& $(1.514)$ & $(1.310)$ \\
Outlier robust & & \\
Estimator & Yes & No \\
Observations & CCE & CCE \\
Number of ifs_code & 367 & 367 \\
\hline
\end{tabular}

Source: Author's calculations.

Notes: See Pesaran (2006) for a full description of the CCE estimator.

\footnotetext{
${ }^{16}$ We also use Pedroni's group mean panel dynamic ordinary least squares estimator as a robustness exercise. While the estimator does not take into account the cross-sectional dependence, it exploits the co-integrating relationship in a more direct way by estimating the co-integrating vector. The results (available on request) confirm the positive and significant long-run relationship between GDP per capita and the value of oil and gas production. By exploiting the co-integrating relationship between the two series we can obtain a consistent estimate of the long-run relationship which is robust to endogeneity, omitted variables and simultaneity.
} 


\section{Figure 5. Long-Run Impact of Value of Oil and Gas Production on GDP Per Capita}

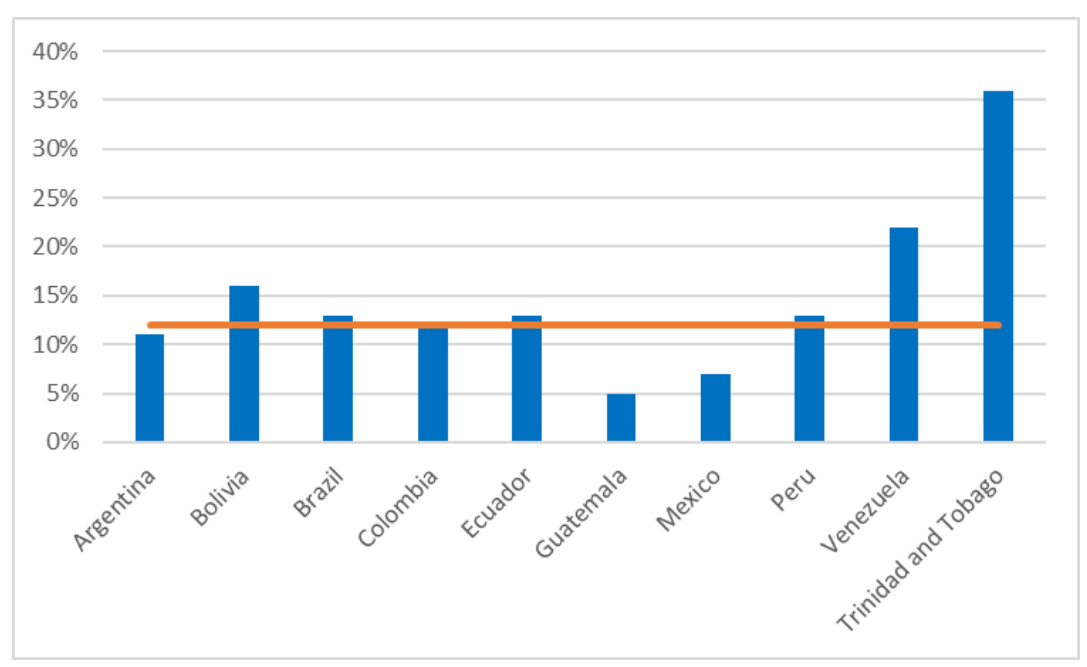

Source: Author's calculations.

\section{The Bolivian Case}

\section{A. Overview and Macroeconomic Developments}

Bolivia has a long history of natural resource extraction, with Potosi having been the largest city in South America in the $16^{\text {th }}$ century due to its large silver mines. Oil production also started early in the $20^{\text {th }}$ century already but only with the large gas discoveries of the 1990s did Bolivia become a major hydrocarbon player. The so-called megacampos allowed Bolivia to increase its gas production volume by a factor of 8 between 1999 and 2015 and made large scale gas exports to Brazil and Argentina possible. Bolivian gas today covers one third of total Brazilian gas demand. Bolivia is also still an important producer of metals, notably zinc, silver and gold but metals contribute relatively less to GDP, exports and fiscal revenues than hydrocarbons. In 2015, the sum of hydrocarbon and metal mining accounted for a total of roughly $13 \%$ of GDP, $80 \%$ of export revenues and $26 \%$ of fiscal revenues (the latter is down from close to $35 \%$ in 2014 ).

Figure 6 highlights the long-term relationship between the (log) real value of oil and gas production and $(\log )$ real GDP per capita in Bolivia. The kink in the early 2000s in both series, as a consequence of the increase in both the volume and value of gas production is immediately apparent. In fact, the experience in Bolivia since the discoveries is well approximated by the cross-country results obtained in section III. Between 2000 and 2014, the real value of oil and gas production per capita in Bolivia increased by about 370 percent, while real GDP per capita increased by 43 percent - very close to the 14 percent long-run relationship estimated for LAC on average and for Bolivia specifically. Should the value of oil and gas production per capita remain substantially below previous levels for an extended period of time, a negative impact on the level of GDP per capita would thus also be likely. 


\section{Figure 6. GDP Per Capita and Value of Oil and Gas Production in Bolivia}

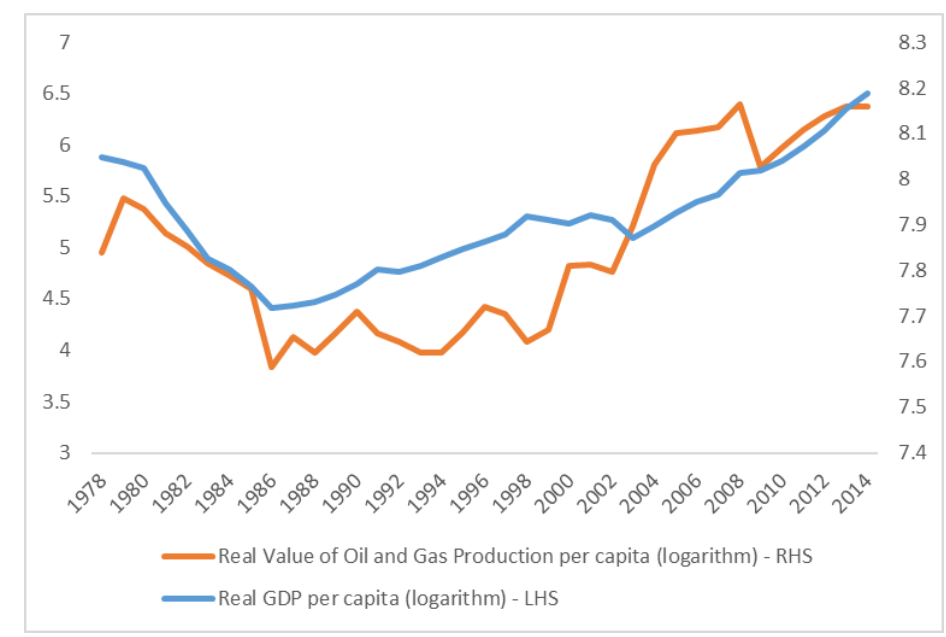

Source: Author's calculations.

\section{B. The Impact of the Natural Resource Boom on Local Economic Development}

Accompanying the improvement in growth and the current account, during the resource boom years, poverty in Bolivia fell dramatically. Balakrishnan et al. (forthcoming) calibrate a heterogeneous agent DSGE model to Bolivia and find that the natural resource boom had a significant impact on nationwide poverty both directly and indirectly through increased government spending. In this section we complement their analysis on the aggregate socioeconomic effects and the insights of the previous sections by studying the local impact of the resource boom in Bolivia. ${ }^{17}$

Between the census of 2001 and 2012, poverty in Bolivia fell from 58.6 percent to 44.9 percent $^{18}$, the share of agricultural employment fell from 31.1 to 26.8 percent and the share of manufacturing employment also fell from 11.7 to 8.9 percent. ${ }^{19}$ Figure 7 shows the distribution of Bolivian municipalities for each of these variables as well as for the residual employment share (mainly various kinds of services, but also public administration, etc.) in 2001 and 2012. A clear shift in the distributions is apparent, implying that the reduction in poverty, and the shifts in the composition of employment were broad-based phenomena across the whole of Bolivia. ${ }^{20}$ For

\footnotetext{
${ }^{17}$ Municipalities are the smallest administrative units in Bolivia (similar to counties in the U.S.). They have some limited autonomy and are mostly financed by transfers from higher levels of government. Departments (similar to U.S. states) are the intermediate unit.

18 The measure of poverty used in this paper is a census based one-the percentage of the population without access to basic necessities (sanitation, water, electricity, adequate living space, etc.). See Feres and Mancero (2001).

${ }^{19}$ Urbanization (fraction of people living in urban areas) increased from 62 percent to 67.5 percent.

${ }^{20}$ Looking at the distributions also tells us that less populated municipalities are poorer and more agricultural given that the mean for Bolivia as a whole (discussed in the text) lie below the mean of the municipalities.
} 
example, the first panel on the left shows the distribution of poverty for Bolivian municipalities in 2001 and 2012. In 2012 the whole distribution has shifted to the left, implying less poverty in virtually every municipality.

Here we are interested in understanding how municipalities which produce natural resources were affected differentially to the rest of the country by the resource boom. To do so, we phrase the analysis in terms of the treatment evaluation literature. The treatment we are interested in is the impact of the natural resource boom on natural resource producing municipalities. The control group is made up of municipalities which do not produce natural resources. For gas producing municipalities our set-up resembles a natural-experiment where we test for the impact of giant gas discoveries. For metal and crude oil producing municipalities, the experiment is somewhat less clean, given that most of them did not have new discoveries, but instead it is a test for the impact of the price boom (which is also plausibly exogenous to Bolivian municipalities). ${ }^{21}$

We use census data at the municipal level for the years 2001 (pre-treatment) and 2012 in the analysis. To test for the impact of the natural resource boom on producing municipalities we estimate the following simple difference in difference regression model

$$
y_{i t}=\alpha+\gamma E M_{i}+\theta T_{t}+\rho\left(E M_{i} * T_{t}\right)+X_{i t}^{\prime} \beta+\varepsilon_{i t} \text { (III) }
$$

where $y_{i t}$ is the dependent variable, $E M_{i}$ is a dummy variable which is 1 for extractive sector municipalities, $T_{t}$ is a time dummy which is 1 in 2012 and the interaction $D_{i t}=\left(E M_{i} * T_{t}\right)$ is the treatment variable, so that $\rho$ is our coefficient of interest. $X_{i t}^{\prime}$ is a vector of municipality and time-varying covariates.

${ }^{21}$ There are 48 municipalities which produce either metal or hydrocarbons (extractive sector municipalities) in Bolivia. 24 produce hydrocarbons and 24 produce metals. 
Figure 7. Poverty Reduction and Change in Employment Composition in Bolivia
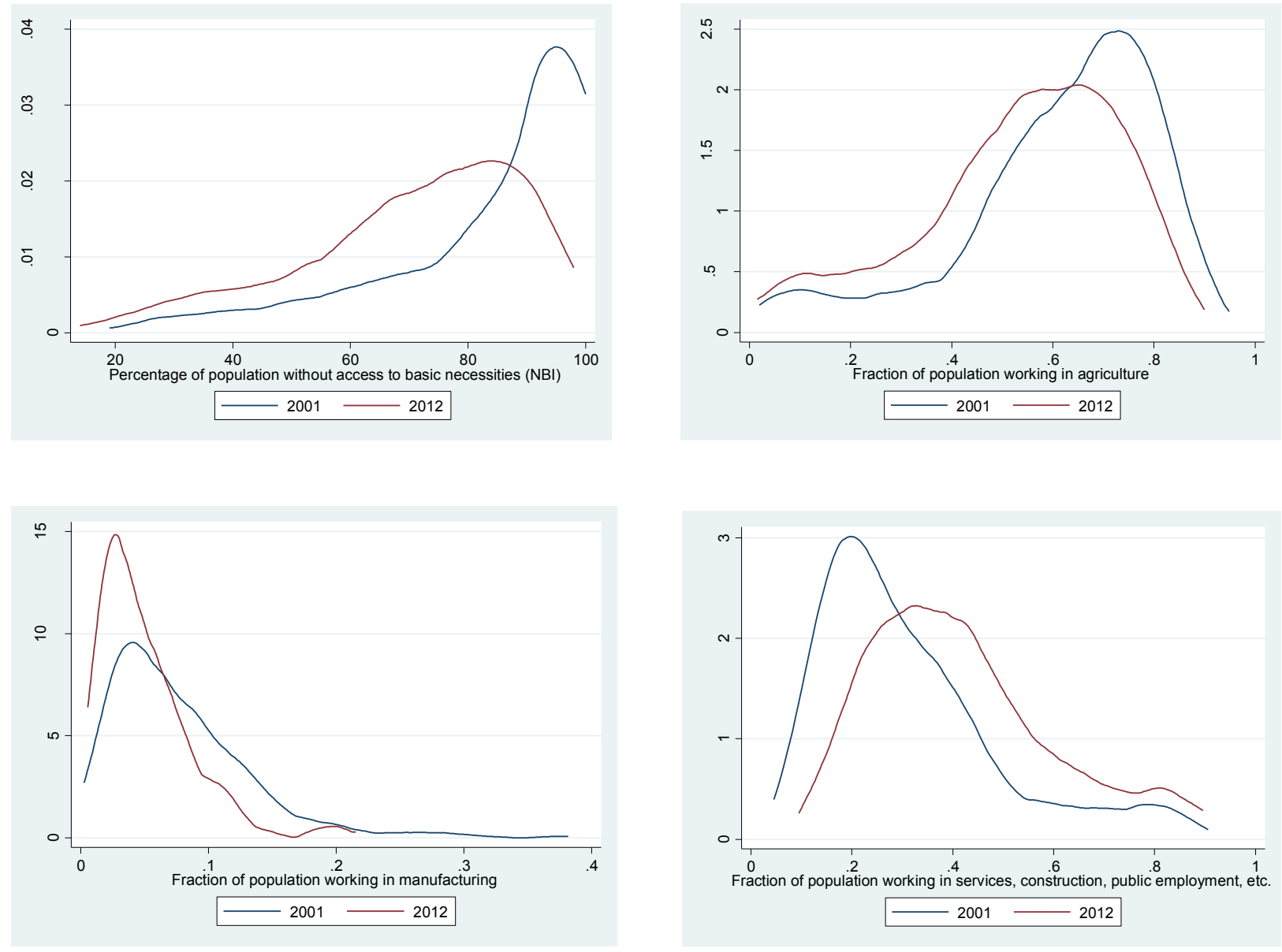

Source: Author's calculations based on INE data.

Before we estimate the regression model, we compare the treatment and control group in the pretreatment period (2001). Comparing the distribution of the dependent variables immediately reveals that they seem to have been quite different already prior to treatment, with average poverty, for example, in extractive sector municipalities significantly lower than in other municipalities. ${ }^{22}$ In fact, the covariate distribution in general is quite different between treatment and control group (see Table 4). ${ }^{23}$ Extractive sector municipalities were less poor, less agricultural and had a higher share of services employment in 2001 than the control group.

To be able to estimate (III) and retrieve a causal coefficient, we need to preprocess the data to guarantee that treated and control municipalities are "similar" prior to treatment. In other words,

\footnotetext{
${ }^{22}$ Since we do not have data prior to 2001, we cannot explicitly test the parallel trend assumption, i.e. we cannot test whether the trends in poverty, etc. in the treatment and control group were the same pre-treatment.

${ }^{23}$ Table 4 shows standardized differences, a simple way to evaluate covariate overlap (see Imbens and Wooldridge, 2009).
} 
we want to compare extractive sector municipalities to municipalities which prior to the resource boom looked very similar to them. There are many techniques to 'pick' a control group which has adequate covariate overlap with the treatment group - mostly based on propensity score methods. Here we use an entropy balancing technique (Hainmueller and $\mathrm{Xu}, 2013$ ) as our baseline. The method assigns weights between 0 and 1 to municipalities in the control group, in order to achieve optimal covariance overlap and then uses those weights in a subsequent regression. It is well suited to our setup where we have many more control municipalities than treatment municipalities. ${ }^{24,25}$

\section{Figure 8. Illustration of Difference in Difference Approach}

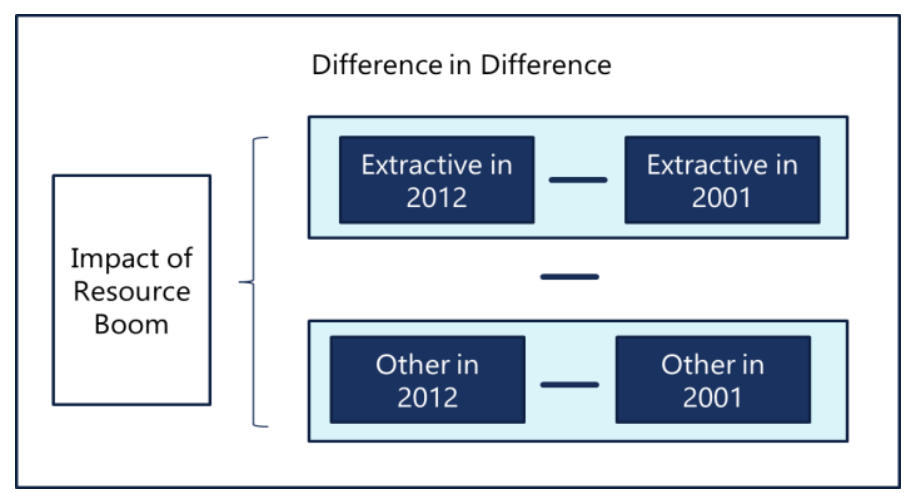

Table 5 shows the baseline results of the impact of the natural resource boom on local economic development in Bolivia. The boom is estimated to have reduced poverty by roughly 3 percentage points in producing municipalities (over and above the reduction in other municipalities). It also increased net migration, reduced the share of workers in agriculture, and increased the share of workers in construction and manufacturing. ${ }^{26}$

Figure 9a presents graphs which plot the result of similar regressions but where we split extractive sector municipalities between metal and hydrocarbon, and additionally differentiate those municipalities in which the megacampos discovered in the late 1990s are located. An interesting picture emerges. Mining municipalities reduced poverty by around 4 percentage points and additionally experienced a reduction in agricultural employment and increases in construction and manufacturing, as well as higher net migration, much as the average results in Table 5, but of slightly larger magnitudes. Municipalities with gas megacampos, on the other hand, experienced double the fall in poverty ( 8 percentage points), manufacturing and

\footnotetext{
${ }^{24}$ Entropy balancing achieves virtually perfect overlap both for the first and the second moment of the distributions. Like the now popular synthetic control method, entropy balancing implicitly makes a strong linearity assumption, however. As a robustness test we also use alternative ways to improve overlap between the treatment and control group. Tables are available on request.

${ }^{25}$ See, for example, Loayza et al. (2013) and Cavalcanti et al. (2016) for related identification strategies to retrieve the impact of natural resource extraction on local socio-economic outcomes.

${ }^{26}$ Recall that the share in manufacturing employment in Bolivia as a whole fell between 2001 and 2012 and the results here are relative to other Bolivian municipalities.
} 
construction increases of a similar magnitude to metal municipalities, no fall in agricultural employment or increase in net migration but an increase in the share of public sector administration employment by roughly 2 percentage points. Other oil and gas municipalities without large discoveries, did not experience a significant impact.

Figure $9 \mathrm{~b}$ puts the magnitude of the estimated coefficients into context by scaling them with the standard deviation of the respective dependent variable. This highlights just how large the increase in public sector administration was in megacampo municipalities. The estimated coefficient suggests that the share of public sector employment increased by over one standard deviation. Similarly, the increase in construction employment in both gas and metal municipalities is large (close to 0.9 standard deviations). The reduction in poverty, evaluated in this way, seems less impressive, however, at only 0.2 and 0.4 standard deviations for metal and gas municipalities, respectively.

Overall it is nevertheless true that the natural resource boom reduced poverty in most extractive sector municipalities and had some positive spillovers to non-extractive sectors in the form of an increase in construction and manufacturing. For mining municipalities, the positive spillovers appear more important, with more evidence of a structural transformation as the fraction of agricultural employment decreased significantly and net migration increased. In megacampo municipalities public sector employment increased very significantly. ${ }^{27}$

\footnotetext{
${ }^{27}$ It is not immediately obvious why there should be no net migration impact in gas municipalities. Even if gas production does not require much labor, construction does and construction increased very significantly in gas municipalities. In fact, the estimated coefficient is large and positive but insignificant. Similarly, the estimated coefficient on agricultural employment has the expected sign (negative) but is insignificant.
} 
Table 4. Standardized Differences in 2001

\begin{tabular}{|c|c|c|c|}
\hline Variable & & Extractive Sector Municipalities & Non-Extractive Sector Municipalities \\
\hline \multirow{3}{*}{ Poverty } & Mean & 75.25 & 85.35 \\
\hline & S.D. & 17.48 & 18.15 \\
\hline & Standardised Difference & & -0.40 \\
\hline \multirow{3}{*}{ Net Migration } & Mean & 2.06 & 2.61 \\
\hline & S.D. & 1.88 & 2.29 \\
\hline & Standardised Difference & & -0.19 \\
\hline \multirow{3}{*}{ Urbanization } & Mean & 0.28 & 0.18 \\
\hline & S.D. & 0.30 & 0.28 \\
\hline & Standardised Difference & & 0.25 \\
\hline \multirow{3}{*}{ Employment } & Mean & 7049 & 8631 \\
\hline & S.D. & 9670 & 33963 \\
\hline & Standardised Difference & & -0.04 \\
\hline \multirow{3}{*}{ Share Empl. Agriculture } & Mean & 0.50 & 0.63 \\
\hline & S.D. & 0.21 & 0.19 \\
\hline & Standardised Difference & & -0.46 \\
\hline \multirow{3}{*}{ Share Empl. Public Sector } & Mean & 0.02 & 0.01 \\
\hline & S.D. & 0.02 & 0.02 \\
\hline & Standardised Difference & & 0.12 \\
\hline \multirow{3}{*}{ Share Empl. Services } & Mean & 0.12 & 0.09 \\
\hline & S.D. & 0.07 & 0.07 \\
\hline & Standardised Difference & & 0.34 \\
\hline \multirow{3}{*}{ Share Empl. Construction } & Mean & 0.05 & 0.05 \\
\hline & S.D. & 0.03 & 0.04 \\
\hline & Standardised Difference & & -0.04 \\
\hline \multirow{4}{*}{ Share Empl. Manufacturing } & Mean & 0.06 & 0.08 \\
\hline & S.D. & 0.03 & 0.06 \\
\hline & Standardised Difference & & -0.26 \\
\hline & Number of Municipalities & 48 & 291 \\
\hline
\end{tabular}

Source: Author's calculations.

Table 5. Impact of Natural Resource Boom on Extractive Sector Municipalities

\begin{tabular}{|c|c|c|c|c|c|c|}
\hline & (1) & $(2)$ & (3) & (4) & (5) & $(6)$ \\
\hline VARIABLES & NBI & In(employment) & $\begin{array}{c}\text { Share Empl. } \\
\text { Agriculture }\end{array}$ & $\begin{array}{c}\text { Net } \\
\text { Migration }\end{array}$ & Urbanization & $\begin{array}{l}\text { Share Empl. } \\
\text { Public Sector }\end{array}$ \\
\hline \multirow[t]{2}{*}{ Treatment (Extractive Sector) } & $-2.752 *$ & 0.0156 & $-0.0523 * * *$ & $1.712 * *$ & 0.354 & 0.000683 \\
\hline & $(1.484)$ & $(0.0445)$ & $(0.0141)$ & $(0.777)$ & $(4.390)$ & $(0.00163)$ \\
\hline \multirow[t]{2}{*}{ Extractive Sector Dummy } & -0.127 & 0.0152 & -0.00379 & 0.00507 & 0.00830 & $-2.04 \mathrm{e}-05$ \\
\hline & $(0.435)$ & $(0.0184)$ & $(0.00482)$ & $(0.206)$ & $(2.632)$ & $(0.000530)$ \\
\hline \multirow[t]{2}{*}{ Year 2012 Dummy } & $-14.79 * * *$ & $0.533^{* * *}$ & $-0.0570 * * *$ & $-1.962 * * *$ & $35.76^{* * *}$ & -0.000389 \\
\hline & $(0.840)$ & $(0.0295)$ & $(0.00804)$ & $(0.429)$ & $(2.640)$ & $(0.000846)$ \\
\hline Observations & 646 & 646 & 646 & 646 & 646 & 644 \\
\hline \multirow[t]{2}{*}{ R-squared } & 0.906 & 0.956 & 0.920 & 0.264 & 0.644 & 0.807 \\
\hline & (7) & $(8)$ & (9) & (10) & $(11)$ & $(12)$ \\
\hline VARIABLES & $\begin{array}{c}\text { Share Empl. } \\
\text { Services }\end{array}$ & $\begin{array}{l}\text { Share Empl. } \\
\text { Construction }\end{array}$ & $\begin{array}{l}\text { Share Empl. } \\
\text { Manufacturing }\end{array}$ & $\begin{array}{l}\text { share Empl. } \\
\text { Commerce }\end{array}$ & $\begin{array}{c}\text { Share Empl. } \\
\text { Education }\end{array}$ & $\begin{array}{c}\text { Share Empl. } \\
\text { Health }\end{array}$ \\
\hline \multirow{2}{*}{ Treatment (Extractive Sector) } & 0.00258 & $0.0189 * *$ & $0.0199 * * *$ & 0.00253 & -0.00151 & -0.000294 \\
\hline & $(0.00802)$ & $(0.00878)$ & $(0.00771)$ & $(0.00770)$ & $(0.00443)$ & $(0.00137)$ \\
\hline \multirow[t]{2}{*}{ Extractive Sector Dummy } & -0.00368 & $-0.0292 * * *$ & $-0.0367 * * *$ & -0.00333 & $4.84 \mathrm{e}-06$ & 0.00120 \\
\hline & $(0.00557)$ & $(0.00690)$ & $(0.00639)$ & $(0.00593)$ & $(0.00301)$ & $(0.000892)$ \\
\hline \multirow[t]{2}{*}{ Year 2012 Dummy } & 0.00152 & -0.00103 & $-0.0382 * * *$ & $0.0113^{*}$ & $-0.00748 * *$ & $0.00444 * * *$ \\
\hline & $(0.00436)$ & $(0.00661)$ & $(0.00581)$ & $(0.00585)$ & $(0.00302)$ & $(0.000792)$ \\
\hline Observations & 646 & 646 & 644 & 646 & 645 & 640 \\
\hline R-squared & 0.781 & 0.299 & 0.395 & 0.791 & 0.339 & 0.594 \\
\hline
\end{tabular}

Controls included are pre-treatment net migration, urbanization, In(employment) and share of workers in the agricultural sector.

Standard errors in parentheses. ${ }^{* * *} p<0.01,{ }^{* *} p<0.05,{ }^{*} p<0.1$ 
Figure 9. Impact of Natural Resource Boom on Extractive Sector Municipalities

(a) in Percentage Points

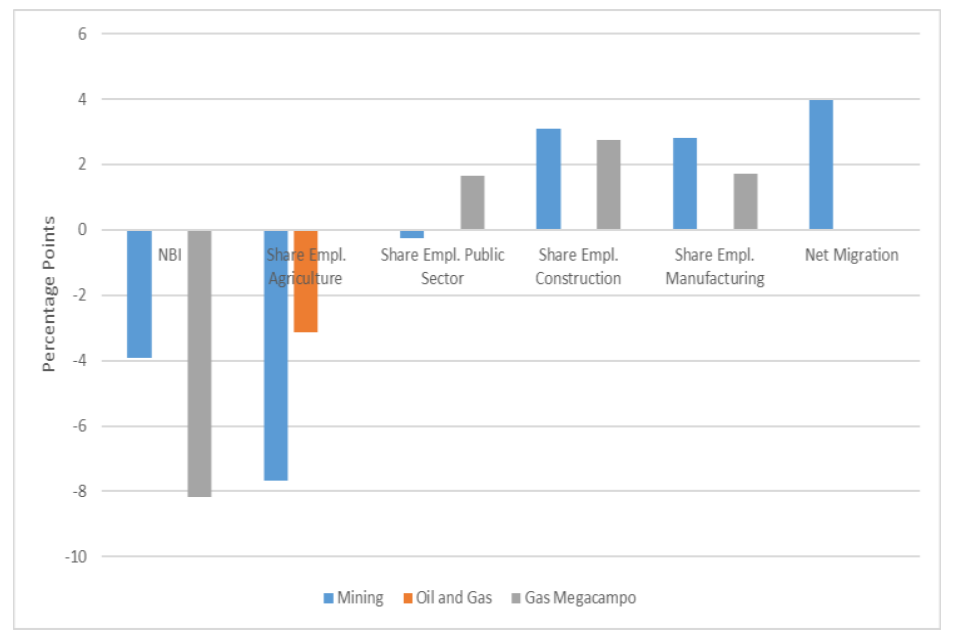

(b) in Fraction of Standard Deviation of Variable in 2012

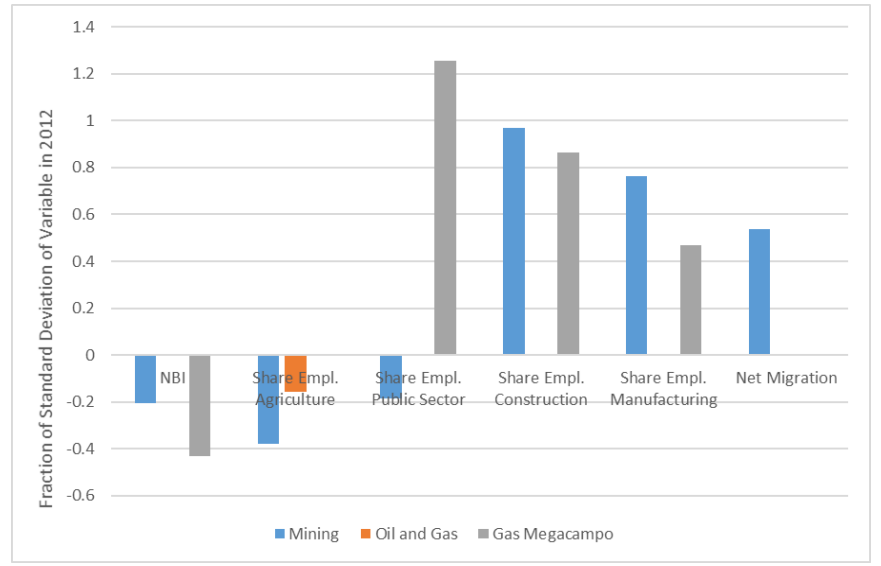

\section{Discussion}

To shed more light on the mechanisms underlying these results it is insightful to consider some salient differences between how metal municipalities and gas municipalities were affected during the boom. A first important difference is the relative labor intensity of mining and gas production, with the former being significantly more labor intensive. On average, in mining municipalities, the share of workers employed in mining is close to 20 percent, while in gas municipalities the share of workers employed in gas production is only around 3 percent. An increase in metal production (as observed in Bolivia as a consequence of higher prices) thus has a much bigger impact on labor demand than an increase in gas production. 
Secondly, municipalities with gas megacampos received a significantly larger fiscal windfall than metal municipalities. In 2012 total fiscal revenues from mining where around 1 percent of GDP, half of which were royalties which are redistributed exclusively to producing departments and municipalities (see Appendix B for more details on distribution of extractive sector revenues). In the same year, total fiscal revenues from hydrocarbons were above 10 percent of GDP — of which around half was distributed to subnational governments.

To illustrate the difference in the size of the fiscal windfall, consider Figure 10, which shows departmental and municipal revenues and expenditures in 2012. ${ }^{28}$ Tarija's budget (the department where all megacampos are at least partly located) was roughly the size of the sum of all other departmental budgets, including those of large states such as Santa Cruz with a much larger population. ${ }^{29}$ As can be seen, the largest part of Tarija's revenues stems from hydrocarbon taxes and royalties directly related to its role as the major producer in Bolivia (roughly 70 percent of total Bolivian gas production). While most of these revenues accrue at the departmental level, Tarija pays 45 percent of its hydrocarbon royalties directly to the semi-autonomous region of Gran Chaco, where a population of roughly 150,000 people thus ends up with an estimated 7 percent of all of Bolivia's hydrocarbon revenues - somewhat below 1 percent of national GDP. The largest recipient of mining royalties (Potosi) on the other hand does not stand out from other departments in terms of revenues per capita.

\section{Figure 10. Departmental Revenues and Expenditures in 2012}

(US\$ per capita)

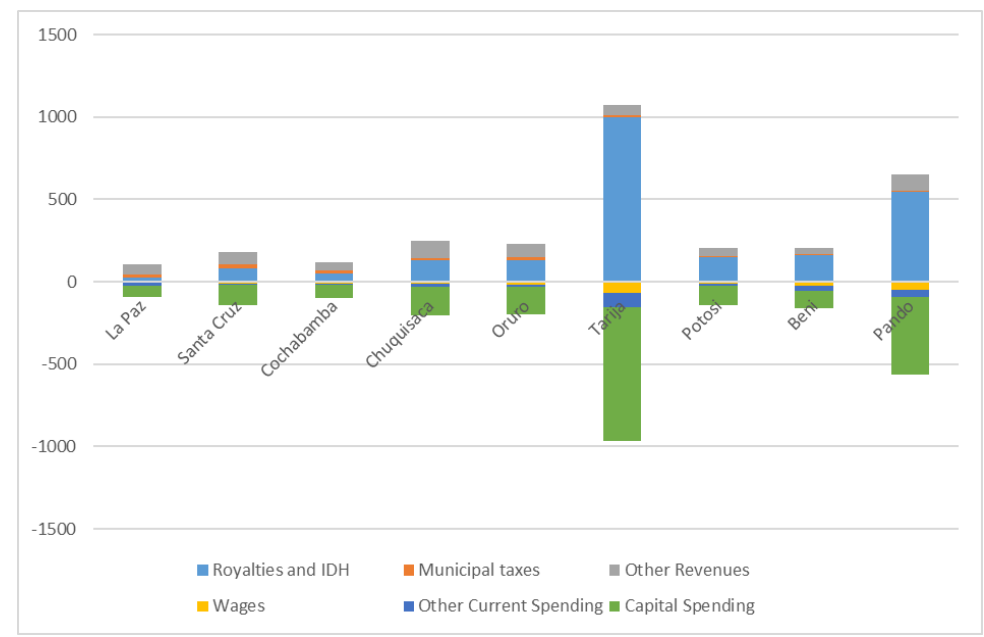

Source: Author's calculations based on Bolivian authorities' data.

A reasonable conjecture thus seems to be that mining municipalities labor demand significantly increased during the boom, triggering a move away from agricultural employment and increasing

\footnotetext{
${ }^{28}$ At the municipal level only data for the capital municipalities was available.

${ }^{29}$ Using data for all municipalities, on a per capita basis, municipal level (but not departmental) revenues are highest in the lightly populated department of Pando (see Sillo and Gomez, 2014).
} 
net migration. Construction and manufacturing activity increased (the latter potentially due to activities directly tied to mining such as smelting) and poverty was reduced as the result of a combination of market forces and increased government spending following the fiscal windfall. In gas municipalities, spillovers were limited due to the low labor intensity of gas production, but the huge fiscal windfall was used by local governments to reduce poverty but also to very significantly increase public sector employment and ramp up construction. ${ }^{30}$ Note that employment in construction and public employment increases but we did not find a significant reduction in the share of employment in any other sectors - given that mechanically the shares have to sum to one, it must be true that employment in other sectors fell, albeit not enough to be picked up in the regressions.

To see whether the municipal level results on the gas boom carry over to the departmental level for Tarija, Figure 11 plots sectoral real GDP growth in Tarija against the rest of Bolivia. It is striking to see that apart from extractive sector GDP, only construction and to some degree public sector administration grew more than in other departments, mirroring the municipal level results. Looking back at figure 10, which showed that even though the wage bill in Tarija is huge (in fact accounting for one third of the total departmental level wage bill in 2012) it nevertheless pales in comparison with the investment expenditures in Tarija which accounted for a staggering 45 percent of total departmental level investment expenditures. It would be interesting to be able to study in more detail the efficiency of this investment and to assess why it does not seem to have led to more spillovers (higher net migration, etc.)

Figure 11. Real Sectoral GDP Growth Tarija vs the Rest of Bolivia

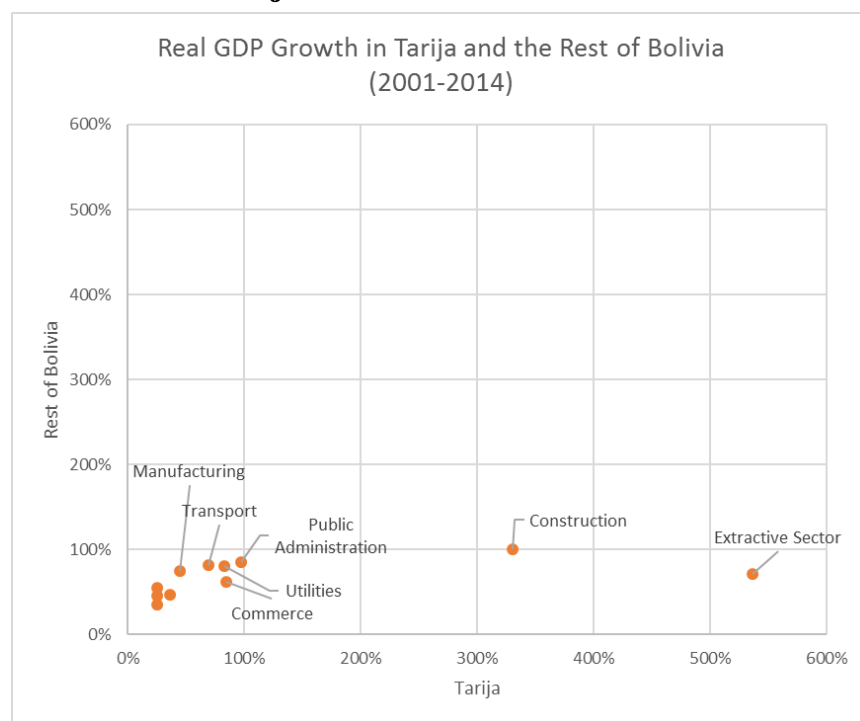

Source: Author's calculations based on INE data.

${ }^{30}$ This result mirrors the result in Caselli and Michaels (2013) on the impact of fiscal windfalls from oil in Brazil. 


\section{CONCLuSion}

This paper studied the impact of natural resource discoveries in LAC countries and at the subnational level in Bolivia and showed that they boost investment and growth in the short-run and then lead to improvements in the current account and fiscal balance over the medium-run. The paper also estimated a positive long-run relationship between GDP per capita and the value of hydrocarbon production, with an elasticity of roughly 14 percent. The paper shows how discovering a valuable asset is at the most basic a positive shock to the economy and highlights the important impact the extractive sector still plays in many national and sub-national economies in the region. An important challenge, which is highlighted by the results at the subnational level in Bolivia, is how to harness the positive fiscall windfall associated with natural resources in a sustainable and efficient way. 


\section{REFERENCES}

Adler, G., and S. Sosa, 2011, "Commodity Price Cycles: The Perils of Mismanaging the Boom," IMF Working Paper No. 11/283 (Washington: International Monetary Fund).

Alexeev, M. and R. Conrad (2009), "The Elusive Curse of Oil”, The Review of Economics and Statistics. 91(3): 586-598.

Allcott, H. and Keniston, D. (2014). Dutch Disease or Agglomeration? The Local Economic Effects of Natural Resource Booms in Modern America. Tech. rep., NBER Working Paper n. 20508.

Aragon, F. M. and Rud, J. P. (2013). Natural resources and local communities: Evidence from a Peruvian gold mine. American Economic Journal: Economic Policy, 5 (2), 1-25.

Arezki, R., V.A. Ramey and L. Sheng (forthcoming), "News Shocks in Open Economies: Evidence from Giant Oil Discoveries", Quarterly Journal of Economics.

Arezki, R. F. van der Ploeg and F. Toscani (2016), "Shifting Frontiers in Global Resource Wealth: The Role of Policies and Institutions", mimeograph.

Balakrishnan, R., M. Mendes Tavares, S.V. Lizarazo Ruiz and A. Peralta Alva (forthcoming), "Distributional consequences of the recent commodity and energy price cycle"

Caselli, F. and Michaels, G. (2013). Do oil windfalls improve living standards?

evidence from brazil. American Economic Journal: Applied Economics, 5 (1), 208-38.

Cavalcanti, T., K. Mohaddes and M. Raissi (2011) "Growth, Development and Natural resources: New Evidence Using a Heterogenous Panel Analysis”, Quarterly Journal of Economics and Finance, 51:305-318.

Cavalcanti, Tiago, Da Mata, Daniel and Frederik Toscani, (2016). Winning the Oil Lottery: The Impact of Natural Resource Discoveries on Growth. IMF Working Paper 16/61. International Monetary Fund, Washington D.C., U.S.

Fundacion Jubileo (2015), "Por que persiste la pobreza en regiones productoras de gas y mineria pese a los ingresos extraordinarios que tuvieron?” (La Paz: Fundacion Jubileo).

Gruss, B. (2014), "After the Boom - Commodity Prices and Economic Growth in Latin America and the Caribbean", IMF Working Paper No. 14/154 (Washington: International Monetary Fund). 
Gylfason, T. , T. Herbertsson and G. Zoega (1999), "A Mixed Blessing”, Macroeconomic Dynamics. 3(2): 204-225.

Hainmueller, J. and Y. Xu (2013) “ebalance: A Stata Package for Entropy Balancing”, Journal of Statistical Software, 54 (7).

Horn, Mike and K. Myron (2014). Giant Oil and Gas Fields of the World.

Imbens, G. W. and J.M. Wooldridge (2009), "Recent developments in the econometrics of program evaluation", Journal of Economic Literature, 47 (1), 5-86.

Inter-American Development Bank (2015). Decentralizing Revenue in Latin America: Why and How. Washington D.C. Inter-American Development Bank.

Loayza, N. and J. Rigolini (2014), “The Local Impact of Mining on Poverty and Inequality: Evidence from the Commodity Boom in Peru", Peruvian Economic Association Working Paper No.33.

Medina, L. (2016) "The Effects of Commodity Price Shocks on Fiscal Aggregates in Latin America", IMF Economic Review, 64.

Michaels, G. (2011). The long term consequences of resource-based specialization. Economic Journal, 121 (551), 31-57.

Monteiro, J. and Ferraz, C. (2012). Does Oil Make Leaders Unaccountable? Evidence from Brazil's offshore oil boom. mimeograph, PUC-Rio.

Pesaran, M.H. (2006), "Estimation and inference in large heterogeneous panels with a multifactor error structure", Econometrica, 74(4): 967-1012.

Pesaran, M.H. (2007), “A Simple Panel Unit Root Test in the Presence of Cross-Section Dependence", Journal of Applied Econometrics, 22:265-312.

Ploeg, Frederick van der (2011). Natural Resources: Curse or Blessing? Journal of Economic Literature, 49(2), 366-420.

Quiroz Sillo, D and J.A. Villegas Gomes (2014) "El Rol del Estado Plurinacional en el Desarrollo Economico: Convergencia o Divergencia en los Municipios en Bolivia? Un Estudio de Convergencia con Metodos Espaciales (1999-2012)" Banco Cental de Bolivia. 
Ross, M. L. (2012). The Oil Curse: How Petroleum Wealth Shapes the Development of Nations. Princeton, New Jersey: Princeton University Press.

Sachs, J.D. and A.M. Warner (1995), "Natural Resource Abundance and Economic Growth", National Bureau of Economic Research. Working Paper 5398.

Traa, B. and A. Carare (2007), “A Government's Net Worth”, Finance \& Development, 44 (Washington: International Monetary Fund).

Tsui, Kevin K., 2011, "More Oil, Less Democracy: Evidence from Worldwide Crude Oil Discoveries,” Economic Journal, Royal Economic Society, Vol. 121, No. 551, pp. 89-115.

Venables, Anthony J. (2016). Using Natural Resources for Development: Why Has It Proven So Difficult?, Journal of Economic Perspectives, 30(1), 161-84.

World Bank (2010), "Natural Resources in Latin America and the Caribbean: Beyond Booms and Busts?", World Bank Latin American and Caribbean Studies (Washington: The World Bank). 


\section{Appendix A. Data}

\section{Construction of Real Value of Oil and Gas Production Data}

We use historical series of nominal and real (in 2015 US\$) Brent crude prices as our oil price measure. For natural gas prices no uniform historical series exist given the fragmentation of the market. We thus proceed as follows. We start with an index of nominal Mexican natural gas prices provided by the OECD. We then use the U.S. natural gas pipeline export price to anchor the Mexican gas price index to obtain a price per million cubic meters which we then apply to the whole of LAC. Lastly, we deflate these nominal prices to obtain real natural gas prices in 2015 US\$.

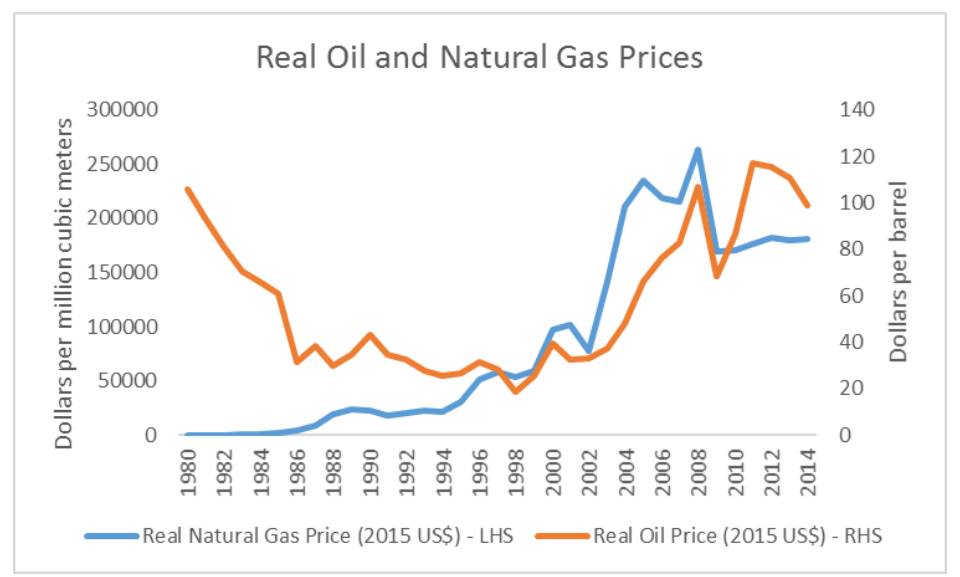

Production volumes of crude oil and natural gas are also taken from the OECD. ${ }^{1}$ To obtain the real value of oil and gas production per capita, we multiply the respective volumes with the real prices, sum the value for oil and natural gas and then divide by population data which we obtain from the International Monetary Fund's World Economic Outlook (IMF WEO) database.

\section{List of Countries Included in the Cross-Country Analysis}

- Section III.B: Argentina, Bolivia, Brazil, Chile, Colombia, Costa Rica, Dominican Republic, Ecuador, El Salvador, Guatemala, Guyana, Honduras, Mexico, Nicaragua, Panama, Paraguay, Peru, Suriname, Trinidad and Tobago, Uruguay, Venezuela

- Section III.C: Producer countries only: Argentina, Bolivia, Brazil, Colombia, Ecuador, Guatemala, Mexico, Peru, Trinidad and Tobago, Venezuela

\footnotetext{
${ }^{1}$ We also use data from BP (2015) in a number of graphs.
} 


\section{List of Extractive Sector Municpalities in Bolivia}

- Hydrocarbon: Monteagudo, Huacareta, Huacaya, Machareti, Entre Rios, Padcaya, Bermejo, Yacuiba, Carapari, Villamontes, Entre Rios (Tarija), La Guardia, El Torno, Warnes, San Juan de Yapacani, Santa Rosa del Sara, Lagunillas, Cabezas, Cuevo, Gutierrez, Camiri, Boyuibe, Postrer Valle, San Pedro

- Metals: Coro Coro, Guanay, Tacacoma, Tipuani, Mapiri, Pelechuco, Quime, Cajuata, Colquiri, Oruro, Caracollo, Antequera, Huanuni, Machacamarca, Yocalla, Llallagua, Colquechaca, Cotagaita, Tupiza, Atocha, Colcha K, Caiza D, Uyuni, Porco 


\section{Appendix B. Brief Description of Extractive Sector Taxation in Bolivia}

\section{Distribution of Taxes to Subnational Government ${ }^{1}$}

Out of the total 18 percent hydrocarbon royalty, 11 percent go to producing departments, 1 percent goes to the lightly populated departments of Pando and Bendi and 6 percent stays with the central government. The 32 percent hydrocarbon tax (IDH) is allocated is a more complicated way, going to both producing and non-producing departments as well as municipalities. Simplifying somewhat, producing departments get roughly $1 / 8$ of the 32 percent, non producing departments get $2 / 8$ and the remainder goes to the central government. The shares allocated to departments are then further split -25 percent stays with the department, 67 percent to municipalities and the remainder to public universities. Mining royalties are distributed only to producing departments and municipalities, with an 85-15 split between the two.

Departments have virtually no other source of revenue and are thus extremely dependent on extractive sector related transfers. Given the high share going to producing departments, they receive significantly more revenue than departments with no or less extractive sector activity. At the municipal level, property taxes are levied and are an important source of revenue, especially in more populous municipalities. Overall, the split in revenues between municipalities and departments was on average 20-80 between 2000-09 in Bolivia (IDB, 2015).

The gas rich department of Tarija has a special arrangement with the semi-autonomous region of Gran Chaco in which large parts of the gas megacampos are located $-45 \%$ of the hydrocarbon royalties which Tarija receives are directly paid to Gran Chaco which then uses these revenues for its own budget, making Gran Chaco a very large received of revenues per capita.

\footnotetext{
${ }^{1}$ This section draws heavily on IDB (2015).
} 


\section{Appendix C. Further Tables and Figures}

\section{Table C.1. Impact of Giant Oil and Gas Discoveries on LAC Economies}

(with lagged dependent variable)

\begin{tabular}{|c|c|c|c|c|c|}
\hline VARIABLES & $\begin{array}{c}\text { (1) } \\
\text { Growth in Value of Oil and Gas Production per Capita }\end{array}$ & $\begin{array}{c}\text { (2) } \\
\text { Growth in Gross Fixed Capital Formation }\end{array}$ & $\begin{array}{c}\text { (3) } \\
\text { Current Account as \% of GDP }\end{array}$ & $\begin{array}{c}\text { (4) } \\
\text { Growth in Real GDP per Capita }\end{array}$ & $\begin{array}{c}(5) \\
\text { Primary balance in \% of GDP }\end{array}$ \\
\hline Growth in Value of Oil and Gas Production per Capita, lagged & $\begin{array}{c}0.0423 \\
(0.0698)\end{array}$ & & & & \\
\hline Growth in Gross Fixed Capital Formation, lagged & & $\begin{array}{c}0.0319 \\
(0.0484)\end{array}$ & & & \\
\hline Current Account as \% of GDP, lagged & & & $\begin{array}{l}0.615^{* * *} \\
(0.0725)\end{array}$ & & \\
\hline Growth in Real GDP per Capita, lagged & & & & $\begin{array}{l}0.281^{* * *} \\
(0.0527)\end{array}$ & \\
\hline Primary balance in $\%$ of GDP, lagged & & & & & $\begin{array}{l}0.532^{* * *} \\
(0.0842)\end{array}$ \\
\hline Volume of discoveries per capita & $\begin{array}{l}-6.92 \mathrm{e}-07 \\
(0.000286)\end{array}$ & $\begin{array}{c}0.000463^{* * *} \\
(0.000148)\end{array}$ & $\begin{array}{l}-0.0156 \\
(0.0184)\end{array}$ & $\begin{array}{l}0.000161^{* * *} \\
(5.23 \mathrm{e}-05)\end{array}$ & $\begin{array}{c}0.00401 \\
(0.00604)\end{array}$ \\
\hline Volume of discoveries per capita, lagged & $\begin{array}{c}0.000222 \\
(0.000174)\end{array}$ & $\begin{array}{l}-0.000729 \\
(0.000446)\end{array}$ & $\begin{array}{l}0.00528 \\
(0.0119)\end{array}$ & $\begin{array}{r}-0.000139 \\
(0.000135)\end{array}$ & $\begin{array}{c}0.00487 \\
(0.00669)\end{array}$ \\
\hline Volume of discoveries per capita, 12 & $\begin{array}{l}0.000364^{*} \\
(0.000184)\end{array}$ & $\begin{array}{l}-0.000228 \\
(0.000431)\end{array}$ & $\begin{array}{c}-0.000297 \\
(0.0101)\end{array}$ & $\begin{array}{l}0.000237^{* *} \\
(0.000104)\end{array}$ & $\begin{array}{l}-0.00335 \\
(0.00260)\end{array}$ \\
\hline Volume of discoveries per capita, 13 & $\begin{array}{c}0.000668 \\
(0.000518)\end{array}$ & $\begin{array}{l}0.000557^{* *} \\
(0.000205)\end{array}$ & $\begin{array}{r}-0.00341 \\
(0.0120)\end{array}$ & $\begin{array}{l}0.000137 \\
(9.77 \mathrm{e}-05)\end{array}$ & $\begin{array}{l}-0.000388 \\
(0.00791)\end{array}$ \\
\hline Volume of discoveries per capita, 14 & $\begin{array}{l}0.000177 \\
(9.87 \mathrm{e}-05)\end{array}$ & $\begin{array}{c}-0.000468 \\
(0.000326)\end{array}$ & $\begin{array}{l}0.00888^{*} \\
(0.00439)\end{array}$ & $\begin{array}{l}-7.89 \mathrm{e}-05^{*} \\
(4.54 \mathrm{e}-05)\end{array}$ & $\begin{array}{l}-0.00334^{* *} \\
(0.00136)\end{array}$ \\
\hline Volume of discoveries per capita, 15 & $\begin{array}{c}0.000427 \\
(0.000426)\end{array}$ & $\begin{array}{c}0.000361 \\
(0.000572)\end{array}$ & $\begin{array}{c}0.0118 \\
(0.00780)\end{array}$ & $\begin{array}{l}-3.01 \mathrm{e}-05 \\
(2.95 \mathrm{e}-05)\end{array}$ & $\begin{array}{c}0.00385 \\
(0.00384)\end{array}$ \\
\hline Volume of discoveries per capita, 16 & $\begin{array}{c}0.000177 \\
(0.000167)\end{array}$ & $\begin{array}{c}-0.00109^{*} \\
(0.000584)\end{array}$ & $\begin{array}{l}0.0268 \\
(0.0193)\end{array}$ & $\begin{array}{c}5.34 \mathrm{e}-05 \\
(8.92 \mathrm{e}-05)\end{array}$ & $\begin{array}{l}-0.00644 \\
(0.0133)\end{array}$ \\
\hline Volume of discoveries per capita, 17 & $\begin{array}{l}-0.000234 \\
(0.000224)\end{array}$ & $\begin{array}{r}-0.000147 \\
(0.000399)\end{array}$ & $\begin{array}{r}-0.00723 \\
(0.00612)\end{array}$ & $\begin{array}{l}-2.72 \mathrm{e}-05 \\
(5.59 \mathrm{e}-05)\end{array}$ & $\begin{array}{c}0.0113 \\
(0.00819)\end{array}$ \\
\hline Volume of discoveries per capita, 18 & $\begin{array}{c}4.76 \mathrm{e}-05 \\
(0.000191)\end{array}$ & $\begin{array}{l}-1.60 \mathrm{e}-05 \\
(0.000316)\end{array}$ & $\begin{array}{l}0.0385 * * * \\
(0.00964)\end{array}$ & $\begin{array}{l}-7.55 \mathrm{e}-05 \\
(6.23 \mathrm{e}-05)\end{array}$ & $\begin{array}{l}0.0222^{* * *} \\
(0.00596)\end{array}$ \\
\hline Volume of discoveries per capita, 19 & $\begin{array}{c}-6.58 \mathrm{e}-05 \\
(0.000224)\end{array}$ & $\begin{array}{c}0.000140 \\
(0.000171)\end{array}$ & $\begin{array}{l}-0.0183 \\
(0.0189)\end{array}$ & $\begin{array}{c}2.83 \mathrm{e}-05 \\
(8.29 \mathrm{e}-05)\end{array}$ & $\begin{array}{l}-0.0131 \\
(0.0123)\end{array}$ \\
\hline Volume of discoveries per capita, 110 & -0.000352 & $-6.54 \mathrm{e}-05$ & 0.0132 & $-1.17 \mathrm{e}-05$ & $0.0166^{* * * *}$ \\
\hline Constant & $\begin{array}{c}(0.000311) \\
0.0266 \\
(0.0752)\end{array}$ & $\begin{array}{c}(0.000300) \\
0.0348 \\
(0.0697)\end{array}$ & $\begin{array}{l}(0.0151) \\
-1.267 \\
(1.077)\end{array}$ & $\begin{array}{c}(8.42 \mathrm{e}-05) \\
-0.000683 \\
(0.0126)\end{array}$ & $\begin{array}{c}(0.00237) \\
2.375 * * * \\
(0.657)\end{array}$ \\
\hline Observations & 364 & 540 & 616 & 616 & 396 \\
\hline R-squared & 0.804 & 0.316 & 0.545 & 0.386 & 0.502 \\
\hline Number of ifs_code & 12 & 19 & 20 & 20 & 20 \\
\hline
\end{tabular}

Robust standard errors in parentheses

${ }^{* * *} p<0.01, * * p<0.05, * p<0.1$

Table C.2. Impact of Natural Resource Boom on Municipalities with Gas Megacampos

\begin{tabular}{|c|c|c|c|c|c|c|}
\hline & (1) & $(2)$ & (3) & $(4)$ & (5) & (6) \\
\hline VARIABLES & NBI & In(employment) & $\begin{array}{l}\text { Share Empl. } \\
\text { Agriculture }\end{array}$ & $\begin{array}{c}\text { Net } \\
\text { Migration }\end{array}$ & Urbanization & $\begin{array}{l}\text { Share Empl. } \\
\text { Public Sector }\end{array}$ \\
\hline \multirow[t]{2}{*}{ Treatment (Gas Megacampo) } & $-8.186 * *$ & -0.00416 & -0.0299 & 3.175 & -3.722 & $0.0164 * *$ \\
\hline & $(4.111)$ & $(0.102)$ & $(0.0355)$ & $(2.081)$ & (10.09) & $(0.00694)$ \\
\hline \multirow[t]{2}{*}{ Gas Megacampo Dummy } & -0.134 & 0.00659 & -0.000786 & 0.140 & -0.325 & 0.000142 \\
\hline & $(1.063)$ & $(0.0213)$ & $(0.0122)$ & $(0.713)$ & $(6.775)$ & $(0.00357)$ \\
\hline \multirow{2}{*}{ Year 2012 Dummy } & $-15.06 * * *$ & $0.590 * * *$ & $-0.0680 * * *$ & $-1.485^{* *}$ & $34.95^{* * *}$ & $-0.00933^{* * *}$ \\
\hline & $(1.370)$ & $(0.0307)$ & $(0.0133)$ & $(0.693)$ & $(4.961)$ & $(0.00319)$ \\
\hline Observations & 646 & 646 & 646 & 646 & 646 & 644 \\
\hline \multirow[t]{2}{*}{ R-squared } & 0.882 & 0.962 & 0.913 & 0.353 & 0.643 & 0.795 \\
\hline & (7) & (8) & (9) & (10) & $(11)$ & $(12)$ \\
\hline VARIABLES & $\begin{array}{c}\text { Share Empl. } \\
\text { Services }\end{array}$ & $\begin{array}{l}\text { Share Empl. } \\
\text { Construction }\end{array}$ & $\begin{array}{l}\text { Share Empl. } \\
\text { Manufacturing }\end{array}$ & $\begin{array}{c}\text { jhare Empl. } \\
\text { Commerce }\end{array}$ & $\begin{array}{c}\text { Share Empl. } \\
\text { Education }\end{array}$ & $\begin{array}{c}\text { Share Empl. } \\
\text { Health }\end{array}$ \\
\hline \multirow[t]{2}{*}{ Treatment (Gas Megacampo) } & 0.00887 & $0.0274^{*}$ & $0.0172^{*}$ & -0.0230 & 0.00676 & 0.00338 \\
\hline & $(0.0144)$ & $(0.0140)$ & $(0.00973)$ & $(0.0164)$ & $(0.00527)$ & (0.00239) \\
\hline \multirow[t]{2}{*}{ Gas Megacampo Dummy } & 0.00566 & -0.00814 & $-0.0342 * * *$ & 0.0207 & -0.000984 & 0.00104 \\
\hline & $(0.00974)$ & $(0.00771)$ & $(0.00771)$ & $(0.0154)$ & $(0.00431)$ & $(0.00170)$ \\
\hline \multirow[t]{2}{*}{ Year 2012 Dummy } & -0.00289 & 0.00240 & $-0.0356 * * *$ & $0.0198 * * *$ & $-0.0125^{* * *}$ & $0.00267 *$ \\
\hline & $(0.00958)$ & $(0.00956)$ & $(0.00774)$ & $(0.00651)$ & $(0.00327)$ & $(0.00156)$ \\
\hline Observations & 646 & 646 & 644 & 646 & 645 & 640 \\
\hline R-squared & 0.870 & 0.400 & 0.445 & 0.859 & 0.362 & 0.633 \\
\hline
\end{tabular}

Controls included are pre-treatment net migration, urbanization, In(employment) and share of workers in the agricultural sector.

Standard errors in parentheses. ${ }^{* * *} p<0.01,{ }^{* *} p<0.05,{ }^{*} p<0.1$ 
Table C.3. Impact of Natural Resource Boom on Municipalities with Metal Mining

\begin{tabular}{|c|c|c|c|c|c|c|}
\hline & (1) & (2) & (3) & (4) & (5) & (6) \\
\hline VARIABLES & $\mathrm{NBI}$ & In(employment) & $\begin{array}{c}\text { Share Empl. } \\
\text { Agriculture }\end{array}$ & $\begin{array}{c}\text { Net } \\
\text { Migration }\end{array}$ & Urbanization & $\begin{array}{l}\text { Share Empl. } \\
\text { Public Sector }\end{array}$ \\
\hline Treatment (Metal Mining) & $\begin{array}{c}-3.922 * * \\
(1.981)\end{array}$ & $\begin{array}{c}0.0413 \\
(0.0506)\end{array}$ & $\begin{array}{c}-0.0767 * * * \\
(0.0216)\end{array}$ & $\begin{array}{c}3.957^{* * *} \\
(0.990)\end{array}$ & $\begin{array}{l}0.0523 \\
(6.822)\end{array}$ & $\begin{array}{c}-0.00242 * * \\
(0.00119)\end{array}$ \\
\hline Metal Mining Dummy & $\begin{array}{c}0.122 \\
(0.458)\end{array}$ & $\begin{array}{l}0.00278 \\
(0.0133)\end{array}$ & $\begin{array}{l}-0.00647 \\
(0.00833)\end{array}$ & $\begin{array}{l}-0.115 \\
(0.311)\end{array}$ & $\begin{array}{c}-0.00667 \\
(4.127)\end{array}$ & $\begin{array}{c}-3.73 e-06 \\
(0.000377)\end{array}$ \\
\hline Year 2012 Dummy & $\begin{array}{c}-16.66^{* * *} \\
(1.105)\end{array}$ & $\begin{array}{c}0.494 * * * \\
(0.0345)\end{array}$ & $\begin{array}{l}-0.0137 \\
(0.0137)\end{array}$ & $\begin{array}{c}-3.249 * * * \\
(0.513)\end{array}$ & $\begin{array}{c}33.10 * * * \\
(4.846)\end{array}$ & $\begin{array}{l}0.00193^{* *} \\
(0.000839)\end{array}$ \\
\hline $\begin{array}{l}\text { Observations } \\
\text { R-squared }\end{array}$ & $\begin{array}{c}646 \\
0.927\end{array}$ & $\begin{array}{c}646 \\
0.972\end{array}$ & $\begin{array}{c}646 \\
0.929\end{array}$ & $\begin{array}{c}646 \\
0.310\end{array}$ & $\begin{array}{c}646 \\
0.632\end{array}$ & $\begin{array}{c}644 \\
0.816\end{array}$ \\
\hline VARIABLES & $\begin{array}{c}(7) \\
\text { Share Empl. } \\
\text { Services }\end{array}$ & $\begin{array}{l}\text { (8) } \\
\text { Share Empl. } \\
\text { Construction }\end{array}$ & $\begin{array}{c}\text { (9) } \\
\text { Share Empl. } \\
\text { Manufacturing }\end{array}$ & $\begin{array}{c}\text { (10) } \\
\text { share Empl. } \\
\text { Commerce }\end{array}$ & $\begin{array}{c}\text { (11) } \\
\text { Share Empl. } \\
\text { Education }\end{array}$ & $\begin{array}{c}(12) \\
\text { Share Empl. } \\
\text { Health }\end{array}$ \\
\hline Treatment (Metal Mining) & $\begin{array}{l}0.00317 \\
(0.0100)\end{array}$ & $\begin{array}{l}0.0308 * \\
(0.0181)\end{array}$ & $\begin{array}{l}0.0280 * * \\
(0.0135)\end{array}$ & $\begin{array}{c}0.0124 \\
(0.0136)\end{array}$ & $\begin{array}{l}-0.00925 \\
(0.00600)\end{array}$ & $\begin{array}{l}-0.00236 \\
(0.00192)\end{array}$ \\
\hline Metal Mining Dummy & $\begin{array}{c}-0.0244 * * * \\
(0.00744)\end{array}$ & $\begin{array}{c}-0.0561 * * * \\
(0.0165)\end{array}$ & $\begin{array}{c}-0.0464 * * * \\
(0.0123)\end{array}$ & $\begin{array}{l}-0.0129 \\
(0.0101)\end{array}$ & $\begin{array}{l}0.000643 \\
(0.00371)\end{array}$ & $\begin{array}{l}-0.000149 \\
(0.00109)\end{array}$ \\
\hline Year 2012 Dummy & $\begin{array}{l}0.000337 \\
(0.00720)\end{array}$ & $\begin{array}{l}-0.0194 \\
(0.0162)\end{array}$ & $\begin{array}{c}-0.0531 * * * \\
(0.0110)\end{array}$ & $\begin{array}{l}0.00426 \\
(0.0118)\end{array}$ & $\begin{array}{l}-0.00402 \\
(0.00467)\end{array}$ & $\begin{array}{c}0.00483 * * * \\
(0.00143)\end{array}$ \\
\hline Observations & 646 & 646 & 644 & 646 & 645 & 640 \\
\hline R-squared & 0.831 & 0.371 & 0.408 & 0.805 & 0.588 & 0.689 \\
\hline
\end{tabular}

\section{Table C.4. Impact of Natural Resource Boom on Municipalities with Natural Resource Production (Control Group Chosen via Propensity Score Matching)}

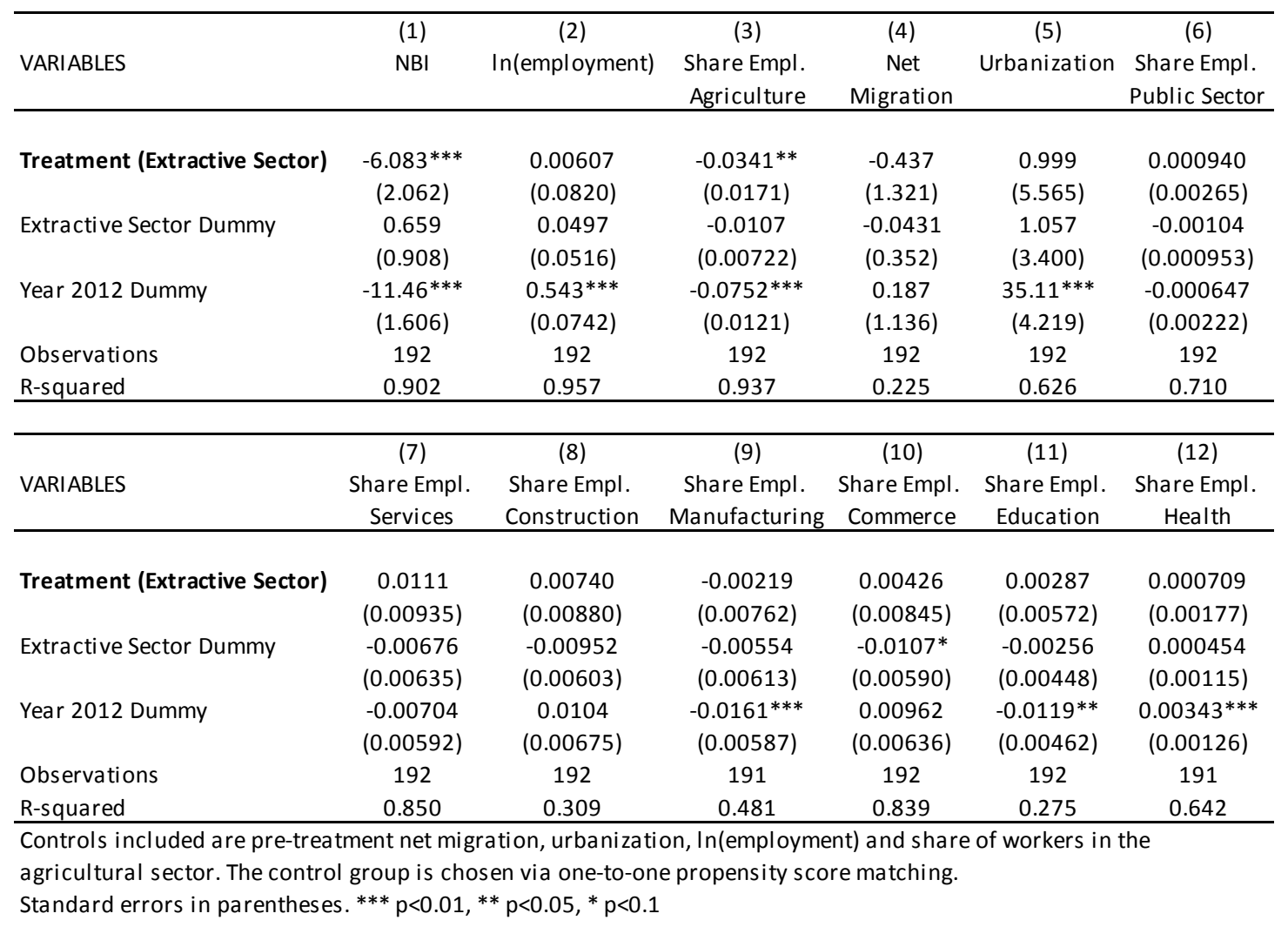

